\title{
Changes and Problems of Conservation in Ankara-Ulus Historical City Center: Koyunpazarı Slope and Atpazarı Square
}

\author{
Filiz Karakuş ${ }^{1}$, Z. Gediz Urak ${ }^{2} \odot$ \\ ${ }^{1}$ Asst. Prof. Dr., Faculty of Architecture and Fine Arts, Ankara Yıldırım Beyazıt University, Ankara, Turkey. (Principal contact \\ for editorial correspondence), Email: ferdemir06@gmail.com \\ ${ }^{2}$ Prof. Dr., Faculty of Architecture, Çankaya University, Ankara, Turkey. Email: gedizu@cankaya.edu.tr
}

\begin{abstract} Purpose

In this study, the settlement located in Koyunpazarı Slope and Hisar (Atpazarı) Square, which has an important position in the Atpazarı-Koyunpazarı-Samanpazarı area, which is the oldest part of the Ankara-Ulus Historical City Center, was examined in a way to include Çengelhan and Çukurhan. With this study, it is aimed to determine the changes and conservation problems in the field and to give direction to the changes planned for the future in the area.

Design/Methodology/Approach

Analysis and evaluation studies conducted in 1998 have been repeated in the mentioned area. Research and surveys have been conducted on the number of buildings in the area, the number of floors, the physical conditions of the buildings, the number of sub-units, types of activities, ownership status, frequency of purchasing goods, types of transportation, spatial competence, infrastructure competencies and future expectations of the working population.

Findings

As a result of these studies, the changes and problems occurred in the period from 1998 to 2020 have been determined. It has been observed that there are serious changes in the area due to cultural tourism, as in all over the world and in our country. The infrastructural deficiencies are the main problems identified in the area. Furthermore, it has been observed that the traffic problem has not been solved completely and also some buildings need repair.

\section{Research Limitations/Implications}

The fact that the field of study could not be expanded due to the application of the survey questions in the field of study in 1998 constitutes the limitations of this study.

\section{Social/Practical Implications}

With this study, it is aimed to draw attention to the conservation of the historical environment in Koyunpazarı Street and Atpazarı Square, which is an important point of the Ulus Historical City Center, and to create a social awareness about the preservation of the area in question.

Originality/Value

This study is significant as it discusses the conservation problems in one of the oldest areas of Ankara and aims to give direction to future changes in the field by formulating proposals for the solution of these problems.
\end{abstract}

Keywords: Ankara, architectural heritage, Atpazarı Square, conservation, Koyunpazarı Slope 


\section{INTRODUCTION}

Tangible or intangible architectural heritage is historical sources that provide important information about the past of societies and must be absolutely preserved. Especially the conservation of the historical environment and areas that have become the symbol of the cities is extremely important in terms of the identity of the cities. The conservation of these environments is only possible by making them suitable for today's living conditions. To achieve this, it is necessary to make a detailed analysis of the mentioned structures and areas, to determine what and how to protect them, and to determine the principles of conservation by considering the needs of today's users.

According to the Ankara-Ulus Development Plan approved in 1989, Koyunpazarı Slope and Atpazarı Square which have been foreseen to be primarily rehabilitated have become the symbol of the city of Ankara due to its being the center of trade and shopping for hundreds of years and is a very important area in terms of the city's identity. This study includes the buildings facing Koyunpazarı Slope and Atpazarı Square, ÇengelhanÇukurhan and Ahi Elvan Mosque (Figure 1,2,3).
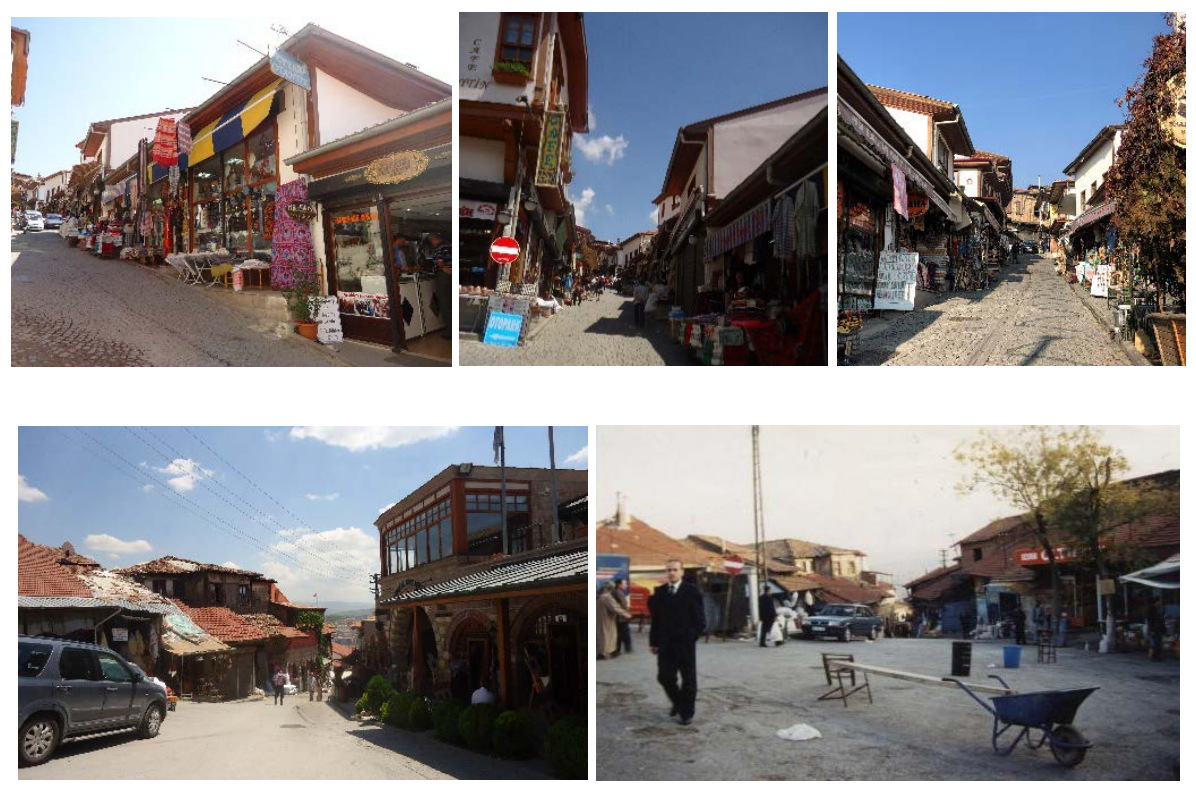

Within the scope of this article, several studies were reviewed in detail such as the study titled "Tarihi Çevre Koruma-Yenileme Çalışmalarında Kentsel Bölge Ölçeği: Ankara Kale Önü Koyunpazarı Yokuşu KorumaGeliştirme Projesi Örneği" prepared by Ziya Utkutuğ and et al., "Ankara Şehir Merkez Gelişimi (14.-20. yy)" by Mehmet Tunçer, the study titled "XVI. Yüzyılda Osmanlı Devleti'nde Çarşı'nın Kent Hayatına Etkisi: Ankara Örneği" prepared by Ziya Dinç, the master's thesis titled "An Exploration Of Urban Soundscape in Ulus, Ankara” prepared by Nehir Bera Biçer, the study titled "The Impacts Of Perception Criteria On Aesthetic Response To Urban Streets: A Case Study in Downtown Ankara, Turkey" prepared by Ayşe Tekel, Aybike Ceylan Kizıltas and Sara Afshar, the study titled "Ankara Hanlar Bölgesi'nin Mekânsal Gelişimi ve Bugünkü Kullanıcı
Figure 1. General view of Koyunpazarı Street (Karakuş, 2020)

Figure 2. View from Atpazarı Square towards Koyunpazarı Street and Çengelhan (Karakuş, 2020) (Urak,1998) 
Changes and Problems of Conservation in Ankara-Ulus Historical City Center: Koyunpazarı Slope and Atpazarı Square

Profilinin Değerlendirilmesi” prepared by Zeynep Çakır, Güliz Bilgin ve Burcu Özüduru, the Doctoral Study "Ankara Çukur, Çengel ve Safran Han Örneklerinde Yeniden Kullanım Müdahalelerinin Koruma Açısından İrdelenmesi ve Bir Değerlendirme Yöntemi Önerisi” prepared by Serap Sevgi and the Doctoral Study "A Tale of Ulus Square: A Critical Assessment of Continuity, Transformation and Change in a Historic Public Open Space in Ankara" by Elif Sena Koçyiğit. It was observed that other studies mentioned other than the study prepared by Utkutug et al., which analyzed the situation of the area in the 1990s, did not focus on conservation problems of area. This study includes a detailed analysis and evaluation of conservation issues and solutions, focusing on changes

Figure 3. Analysis of addresses and borders (Karakuş, 2020)

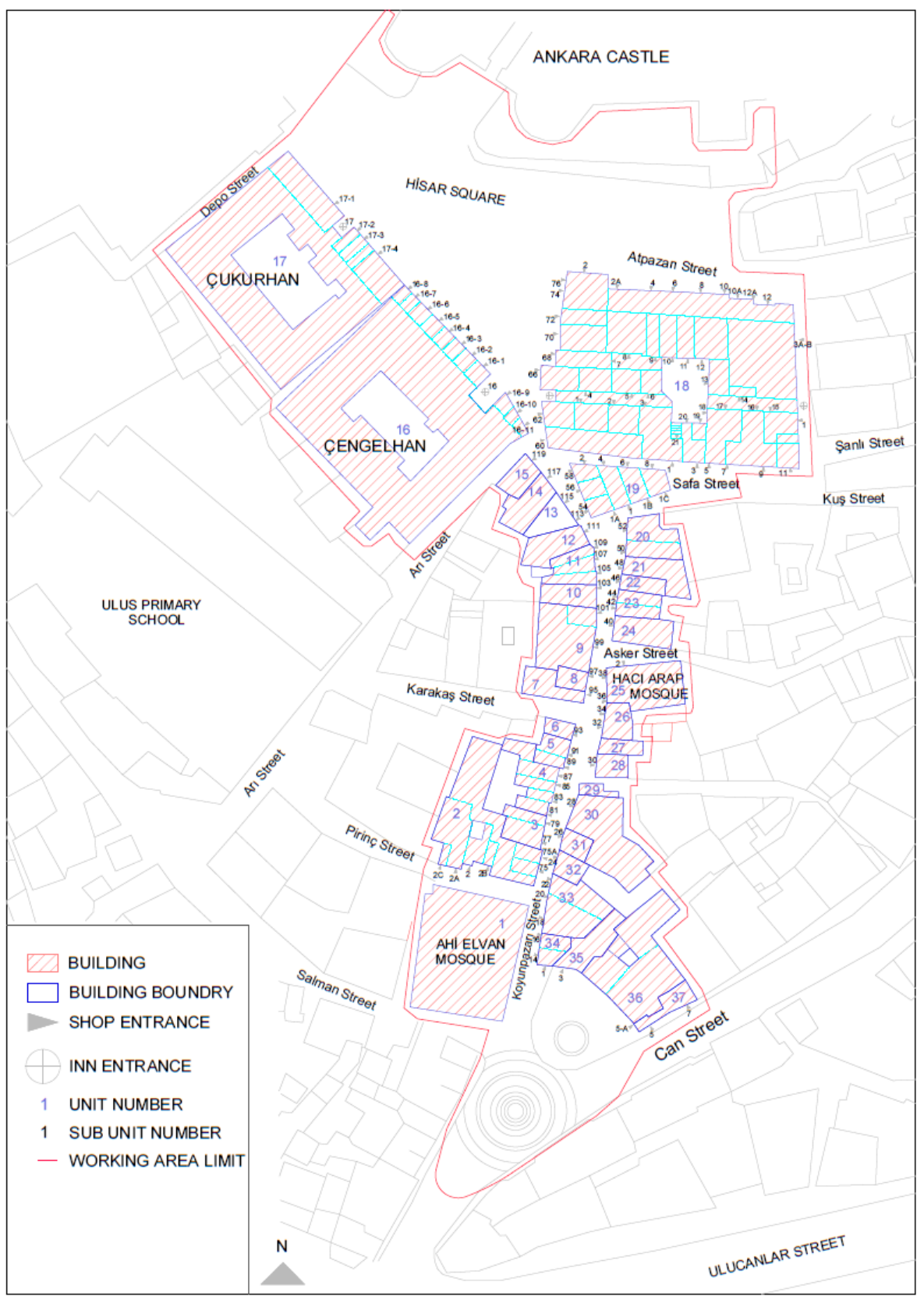


seen in the field after the 1990s. In this way, it is considered to be important because it aims to fill a gap regarding the literature on Koyunpazarı Street and Atpazarı Square.

\section{METHODOLOGY}

In this study, literature and resource scanning was carried out primarily on the historical development of the field of study and the development of conservation in the world. The maps and plans of the area covering the 1998 study were re-examined on site, and updates on the structures were made on these plans. The data obtained in the field of study were obtained by determinations, surveys and observations from 37 main units and 100 subunits (each of the commercial units in a main structure) located in Koyunpazarı Slope and Atpazarı Square. In the surveys and observations, the number of structures, the number of floors and their physical condition, their use of space in subunits and the types of activities were emphasized. Surveys conducted in commercial units focused on socio-economic characteristics such as property structure, market and environmental relations, frequency of purchase of goods and types of transportation used, spatial competence, infrastructure adequacy and future expectations of the working population. For this purpose, the survey questions prepared for each commercial unit were carried out by face-to-face interview method. The surveys were then transferred to the computer environment and compared with the results obtained in the analysis and surveys conducted by Mrs. Z. Gediz Urak in the same field in 1998. In the intervening period, changes in the field were detected and the reasons for these changes were emphasized. It has been observed that there are significant changes in the type of activity in commercial units depending on cultural tourism as in the whole world and in our country. It has been observed that the old types of activity cannot be preserved in the area that has an important place in the commercial life of Ankara city in the past, and infrastructure problems cannot be solved and an integrated conservation approach cannot be put forward. In this study, solutions to the conservation problems identified were tried to be presented.

\section{THEORETICAL FRAMEWORK}

It is seen that the first efforts to protect were carried out for the protection of places of worship. Such protection activities were also frequently seen in Ancient Egypt and Mesopotamia (Erder, 1975), and interventions made at that time were carried out in order to maintain the existence of structures depending on their religious, symbolic, political roles and meanings rather than protection (Jokilehto, 1999). The preservation of ancient buildings during the Roman Empire, when the city was considered as a work of art as a whole, was one of the important issues (Erder, 1971). The effect of religion on conservation approaches did not always yield positive results. As a matter of fact, to spread 
Changes and Problems of Conservation in Ankara-Ulus Historical City Center: Koyunpazarı Slope and Atpazarı Square

Christianity faster, structures representing other religions were tried to be eliminated and there were significant destructions (Erder, 1975).

Since the 14th century, interest in monumental buildings and works of art from ancient times started to increase, and interventions to protect them became more conscious (Erder, 1975). Since the 16th century, the view was formed that art works and historical buildings were worth preserving because they were expressions of a culture or national identity (Jokilehto, 1999).

The idea of conservation, born in the 18th century in response to the destruction of the French Revolution, developed in France under the leadership of Eugene Emmanuel Viollet-le-Duc (Ashurst, 2007; Kuban, 2000). The romantic movement under the leadership of John Ruskin emerged against the stylistic method of recomposition (Ahunbay, 1996; Kuban, 2000). According to this current, no changes should be made to the building in the name of restoration. In England, William Morris supported this movement (Ahunbay, 1996). Opinions on restoration developed over time, and in the late 1800s, historical restoration and contemporary restoration movements were born. It is seen that the first legal studies for the protection of architectural monuments were carried out in the late 18th century and early 19th century, during which the concept of historical monuments emerged.

The Athens Charter, prepared after the conference in Athens in 1931, discussed the necessity of preserving monumental structures together with their surroundings and the need to use modern methods to repair them (Ahunbay, 1996; Binan, 1999; Erder, 1975; ICOMOS, 1931, Athens Charter). ICCROM (International Center for the Study of the Preservation and Restoration of Cultural Property) was established in 1959 under the leadership of UNESCO (Binan, 1999).

At the 1964 conference in Venice, indiscriminate and different interventions in historical buildings were criticized and the convention adopted the rule of respecting the traces of all periods. With the Venice Charter, the concept of monuments has been redefined and expanded from a single structure to include urban or rural settlements that witness a certain civilization and/or a significant development and a historical event (Ahunbay, 1996; Erder, 1975; ICOMOS, 1964, Venice Charter). ICOMOS (International Council on Monuments and Sites) was established in Warsaw in 1965.

1975 was declared as the year of European Architectural Heritage, and the European Architectural Heritage Charter was prepared in the same year. With these bylaws, the concept of architectural heritage has been replaced by the concept of historical environment. Important approaches such as the universal value of the historical environment, the integrated conservation approach that seeks to establish the right relations between conservation-economy and social structure, and the tools for its implementation are included (Mazl, 2009). With the Amsterdam Declaration prepared in the same year, it is stated that architectural heritage is in danger and the planning method that can prevent these 
dangers is integrated conservation (ICOMOS, 1975, Amsterdam Declaration).

The Burra Charter, which is used as a guide for the protection and management of cultural heritage sites, was adopted by Australian ICOMOS members in 1979. The charter set out the purpose of protection as the maintenance of the cultural value of the area and the consideration of its safety, care and future, and determined the ten principles of protection (ICOMOS Australia, 1999, Burra Charter).

In 1985, the Council of Europe adopted the Convention on the Protection of Architectural Heritage of Europe and emphasized that the cultural assets to be protected by this Convention should be remarkable in historical, archaeological, artistic, scientific, social and technical respects, and it was emphasized that cultural assets are a source of creativity for all mankind (Council of Europe, 1985).

Adopted by ICOMOS in Washington in 1987, the Regulation on the Protection of Historic Cities and Urban Areas sets out the principles, goals and methods for the protection of historical cities and areas. With this regulation, it is stated that socio-economic development should be ensured for the protection of historical cities and urban areas and that it is of great importance that urban policies work in integrity and that the participation of the city's people is a prerequisite for the success of conservation programs (ICOMOS, 1987, Washington Charter). With the Nara Certificate of Authenticity adopted after the Nara Originality Conference held in Nara, Japan, the idea that authenticity should be taken into account in the protection of cultural and architectural heritage in the world has been adopted (ICOMOS, 1994, Nara Certificate of Authenticity). As a result of developments such as the 2002 Budapest Declaration, the 2008 Quebec Congress on the Perception and Presentation of Cultural Heritage Sites, the Valetta Principles for the Protection and Management of Historic Cities and Urban Areas in 2011, the Functional Principles implementation Guide to the Implementation of the 2013 World Heritage Convention, and the 2014 Florence Declaration, the conservation approach has taken a contemporary place. In the process, people's approach to the concept of protection has changed on an individual and community scale and the importance given to protection has increased greatly around the world.

Apart from the developments in conservation, cultural tourism has been another issue affecting the historical environment and architectural heritage. Cultural tourism began to be considered a separate category of tourism in the late 1970s, with the realization by tourism marketers and researchers that some people were traveling to understand the culture or heritage of a region in more depth (Tighe, 1986). Cultural tourism was initially conceived as a private and niche activity, thought to be after a smaller number of better educated, wealthier tourists looking for something other than a standard sand, sun and sea holiday, but in the 1990s it was considered a high-profile and mass type of activity (Richards, 1996). Cultural tourism is a type of tourism activity where the 
Changes and Problems of Conservation in Ankara-Ulus Historical City Center: Koyunpazarı Slope and Atpazarı Square

main motivation of the visitor is to learn, discover, experience and consume cultural attractions and products that are tangible and not in a tourist destination (Richards, 2018). Tourists participating in cultural tourism aim to watch and participate in archaeological sites and museums, historical and cultural heritage, art galleries, festivals, sculptures, music and dance events, religious festivals (Richards, 2001; Küçükaltan et al., 2005). Artifacts and historical circles that bear traces of ancient lives are of great importance for cultural tourism as a result of being able to draw attention to them.

The marketing of cities and regions has become an important issue (Giritlioğlu \& Avcıkurt, 2010), with the tourism sector, which was previously used only as a means of national development and supported in this direction, later becoming a supporter of local, regional and urban development (Tosun \& Bilim, 2004). This situation has led to the emergence of activities aimed at ensuring that the touristic features of each region are presented by revealing them. In our country, cultural tourism studies have been carried out by relevant institutions and organizations in many cities and regions.

Visiting cultural assets by tourists can provide a variety of benefits to local people and governments. First of all, historical, cultural and natural areas are protected in this way. In addition, cultural or heritage tourism is very important for both locals and tourists to know about the history and culture of the region (Huh, 2002). The most important of the positive effects of tourism on cultural assets is the economic effects of local people, such as raising the level of life and creating new jobs. Economic development brings with it socio-cultural development. Increasing the public awareness of the local population also increases investments in conservation (Akgül, 2003).

On the cultural assets of tourism, it has negative effects such as overuse of tourists, commitment to tourism, tourist behavior, unregulated tourism infrastructures, loss of control over cultural features, physical deterioration of assets (McKercher \& Cros, 2002). The growth of cultural tourism coincided with the acceptance by a wider society of the need to protect and preserve our diminishing cultural and heritage assets. As a result, cultural heritage management advocates have begun to publish policies to protect cultural values from inappropriate tourism uses (ICOMOS, 1976). It has been adopted by the International Cultural Heritage Charter that tourism should bring benefits to the host community, provide them with opportunities to preserve and maintain their cultural heritage and cultural traditions, and establish a sustainable tourism industry (ICOMOS,1999). The concept of sustainability, which gains importance in all areas of life, also gains importance in tourism. Sustainable tourism, which includes social responsibility, economic efficiency and ecological sensitivity at every stage, is defined as planning and carrying out tourism activities by ensuring the protection and continuity of all natural, cultural, ecological and biological resources in parallel with tourism developments (Beyhan \& Ünügör, 2005). In 
sustainable tourism, it constitutes the main goal of development by preserving future opportunities, meeting the needs of traditional settlements and existing tourists without destroying natural and cultural resources and putting the environment first (Avclkurt, 1997).

\section{HISTIRICAL DEVELOPMENT OF THE AREA}

The establishment of the city of Ankara dates back to $4000 \mathrm{BC}$, and the city sometimes became a provincial center that lived in peace and was equipped with monuments, sometimes it gained importance as an important military garrison, a commercial and industrial city on the main roads, and sometimes it was inundated and destroyed by invasions (Bakırer \& Madran, 1984).

Founded in Kırsehir in the 13th century by Nasırüddin Ahi Mahmut Evran and organized primarily by leather workers, the Ahi-order spread rapidly in Ankara. Leathering has taken a very important place in economic life due to the widespread livestock in the city (Kosay, 1935). In the same period, it is known that sof weaving has developed as well as leathering and Ankara "sof" (mohair) is known worldwide (Akdağ, 1974). During this period, the plain just outside the Citadel Gate of the castle ${ }^{1}$ serves as a "marketplace", and in the following years, the inns built around this marketplace developed trade in the city together. Starting in the 14th century, the function of Ankara as a "border city" changed and began to gain the function of "commercial city" (Aktüre, 1984). In Ankara, it is seen that commercial activities are concentrated on the road connecting Atpazarı Square and the castle to the caravan roads outside the "Dışkale" gate (Tunçer, 2001).

It is seen that the important buildings built by the Ahi People in Ankara are concentrated in Atpazarı Square, the oldest center of the city (Figure 4) (Tunçer, 2001). The construction of these structures directly affected the development of the neighborhoods and trade center in the aforementioned area. During this period, it is known from various studies that "sof" (mohair) trade was carried out in Mahmut Pasha Bedesten (Covered Bazaar) (Bakırer \& Madran, 1984), which was built in the late 15th century on the Abacılar Slope leading west from Atpazarı Square, and that numerous inns operated around Mahmut Pasha Bedesten (Aktüre, 1978; Bakırer \& Madran, 1984; Aktüre, 2001). In the 16th century, Bedesten, the oldest parts of the castle and the city, the Khans District and part of the Long Bazaar were named "Yukarıyüz" (Figure 5), and the part under today's Anafartalar Street, which extends from Hacl Bayram Mosque to Karacabey Complex, was named "Așağıyüz" (Tunçer, 2001; Bakırer \& Madran, 1984). The center of "Yukarıyüz" is Atpazarı. In and around Atpazarı, Bedesten, along with Mahmut Pasha Inn, Uzunçarşı and the artisan bazaars and inns leading to it were located. The center of "Așağıyüz" is Tahtakale (Kaledibi). Here, Hasan Pasha Inn and the surrounding bazaars and Haseki Mosque are two important elements (Ergenç, 1984). The area between Atpazarı and Koyunpazarı, where the Ahi Elvan Mosque, Hacı Arab Mosque and Ahi Şerafettin Mosque are
1 This plain is called Atpazarı Bazaar by Ziya Dinç, and it is written that there are shops composed mostly of peddlers and animal trading is also carried out. 
Figure 4. Ankara Khans Region is drawn in line with Ankara Cadastral Maps dated 1929 (Tunçer, 2001: 22)

Figure 5. Commercial center formed in the upper part of Ankara in the 16th and 18th centuries (Aktüre, 1978: 119)
Changes and Problems of Conservation in Ankara-Ulus Historical City Center: Koyunpazarı Slope and Atpazarı Square

located, has grown as an important religious center for the city and commercial activities have developed around the mosques in this religious center. Small-scale commercial activities consisted of peddling, blacksmithing, copper making and animal-related shopping, while largescale commercial activities consisted of inn buildings where mohair trade was carried out (Biçer, 2019; Koçyiğit, 2018).

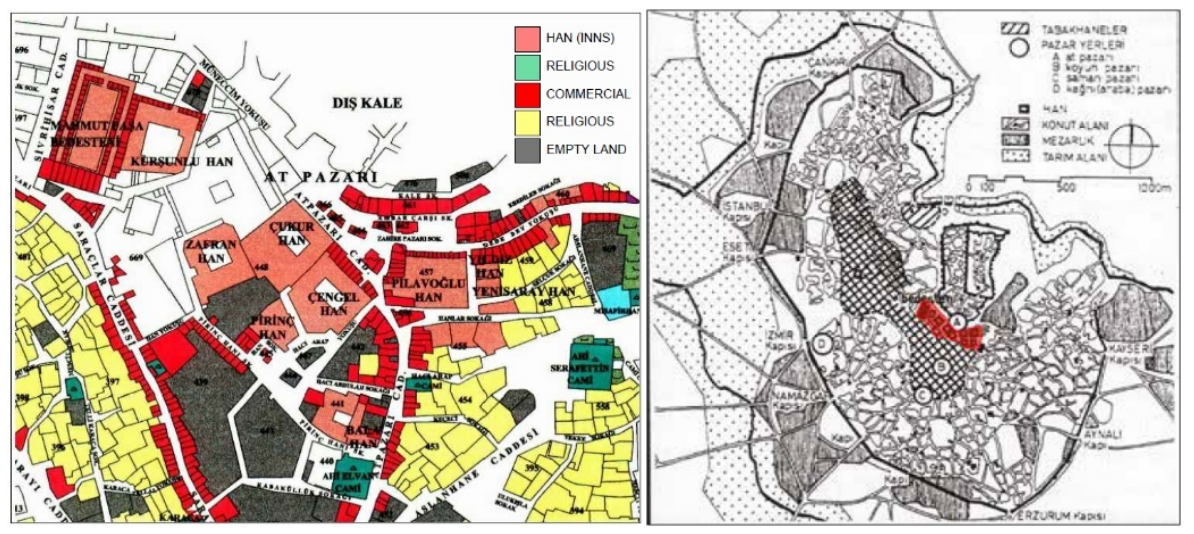

Ankara has been rich in agriculture and animal products for a very long time and has been trading its own products (Bakırer \& Madran, 1984). Especially in the 15th and 16th centuries, it became a vibrant art and commercial city that sold its agricultural products, and the "sof" fabrics it produced in the eastern and western markets (Bakırer \& Madran, 1984; Ergenç, 1984). As in Ottoman-Turkish cities, live animals were traded in open markets in Ankara, and there were neighborhoods such as "Samanpazarı", "Odunpazarı", "Koyunpazarı", "Atpazarı" and "Balıkpazarı" (Tunçer, 2001).

In Ankara, which experienced its brightest period commercially in the 16th and 17th centuries, an economic collapse began due to the decline of production activities by the end of the 19th century and the city lost its status as a trade center (Aktüre, 2001). With the decline of lint exports in the 1850s, inn structures that had an important place in lint ("sof") trade and storage began to lose their function (Biçer, 2019; Tunçer, 2014). In the fire of 1916, Mahmut Pasha Bedesten and Atpazarı Square were greatly affected (Tunçer, 2014; Aktüre, 2001) and Atpazarı Square and its surroundings completely lost their importance to the city (Koçyiğit, 2018).

With the declaration of Ankara as the capital in 1923, the city regained its importance and began to reshape as planning activities accelerated (Çakır et al., 2019). In line with the Jansen Plan approved in 1932, various trade and production activities were carried in this direction with the relocation of ministry buildings to the Red Crescent (Kizllay) direction (Tankut, 1984). As a result of the gradual shift of the city center in Kizllay to the south, the region has undergone new transformations in approximately 15-year periods (Utkutuğ et al., 1993). 
With the rapid population growth and intensive construction that emerged after Ankara became the capital, the Khans Region has become a neighborhood of the city. Although the area remains commercial, it remains in the poor part of the city. Due to the fact that it remains within the area shown as "Protocol Area" in the prepared zoning plans and is located outside the main road network, it has been preserved to a certain extent taking into account its cultural importance (Urak, 1999).

The Ankara Nazım Zoning Plan, which was started to be prepared by the Ankara Metropolitan Area Zoning Planning Bureau in 1973, was approved and entered into force in 1982. In this plan, it was decided to develop the Central Business Areas towards the area called "Kazıkiçi Bostans" located west of Çankırı Street in order to ensure the protection and development of Ulus Historical City Center (Tunçer \& Cengizkan, 1996). No implementation took place in the field until the National Zoning Plan was approved in 1989, the primary purpose of which was both the revival and physical renewal of the functional structure of the Nation, which left its basic functions to the Kizllay over time. One of the projects prepared in this direction was approved in 1991 by the Department of Architecture, Keklik Street and Environment Protection Development Project developed by the Department of Architecture of Middle East Technical University, and in 1991, the Koyunpazari Slope and Environment Protection Development Project prepared by the Department of Architecture of Gazi University Faculty of Engineering and Architecture were approved but could not be implemented (Urak, 1999). In the study conducted by Utkutug et al., they found that during each transformation process in the field, the sub-sociocultural groups that came to the region tended to change the physical environment in parallel with the new functions in line with the requirements. Especially traditional houses have lost their originality by losing their courtyards, dividing or receiving add-ons from the renovations carried out in this process (Utkutuğ et al., 1993).

While all of Çengelhan was registered on behalf of Ankara Metropolitan Municipality, the deed was canceled according to the law no. 7044 and registered on behalf of the General Directorate of Foundations in 1997, and the necessary expropriation procedures were carried out by the General Directorate of Foundations (Ankara Regional Directorate of Foundations Archive). With the decision of Ankara Council for the Protection of Cultural and Natural Assets dated 25/01/2002 and numbered 7741, survey projects, conservation, repair and re-functioning projects were approved with the decision dated 15/08/2003 and numbered 8715. In 2000, the inn was leased for 18 years as part of the Restore-Operate-Transfer tender made by the Ankara Regional Directorate of Foundations and has been functioning as Rahmi Koç Museum since 2005 (Figure 6) (Sevgi, 2020; Aksoy, 2010). 
Figure 6. Cengelhan after restoration (Karakuş, 2015)

Figure 7. Çukurhan after restoration (Karakuş, 2017)
Changes and Problems of Conservation in Ankara-Ulus Historical City Center: Koyunpazarı Slope and Atpazarı Square

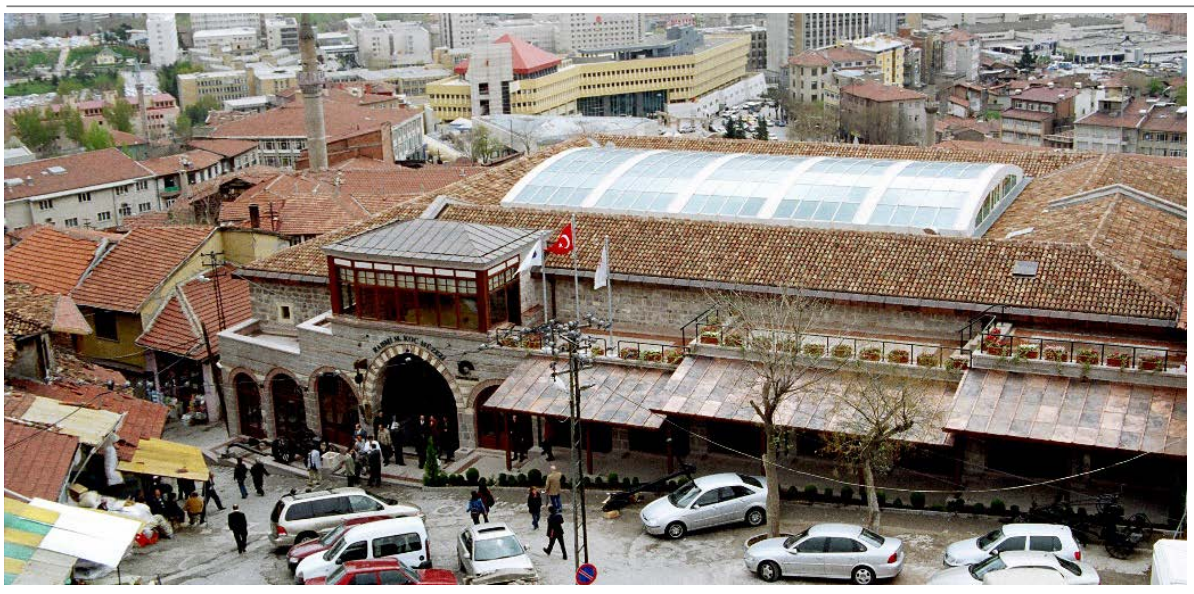

Çukurhan was registered on behalf of the General Directorate of Foundations (Ankara Regional Directorate of Foundations Archive) as a result of the lawsuit to resolve the partnership, which started in 2003 and concluded in 2004. Çukurhan's survey projects were approved by the Decision of the Ankara Regional Council for the Protection of Cultural and Natural Assets dated 2/2/2007 and numbered 2089, while the restitution, restoration projects and reports were approved by the Ankara Renewal Area Cultural and Natural Assets Protection Regional Board on 11/05/2007 and numbered 24. Çukurhan's Restore-OperateTransfer tender was held in 2006 by the Ankara Regional Directorate of Foundations and the inn has been leased for 29 years and has been used as a boutique hotel since 2010 (Figure 7) (Sevgi, 2020; Aksoy, 2010).

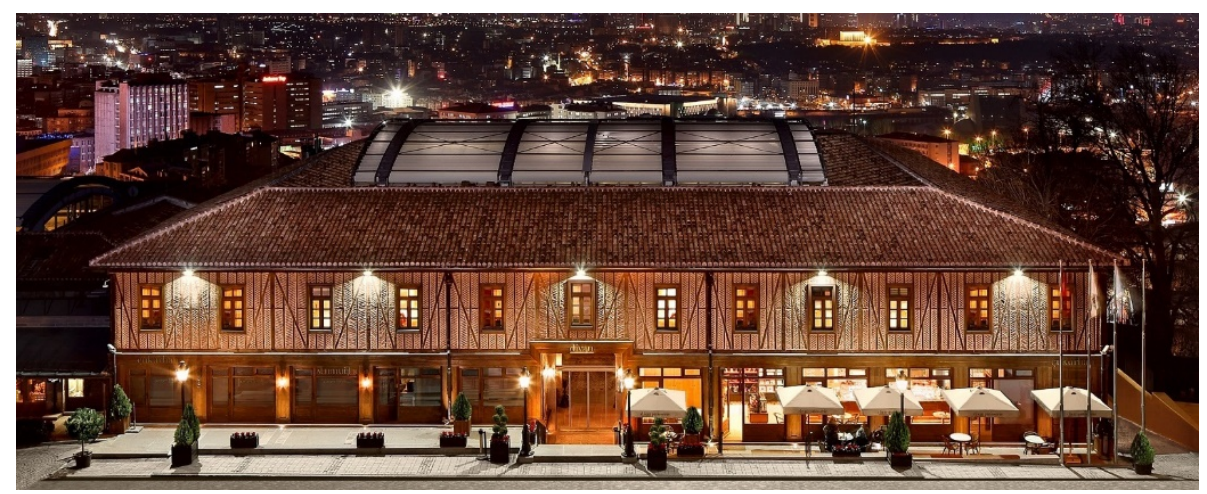

"Koyunpazari Street Rehabilitation Project" (Figure 8) prepared by Mimor Architecture Office was approved by the Ankara Renewal Area Regional Council for the Protection of Cultural and Natural Assets on 04/07/2008 and numbered 189. The "Can Street Rehabilitation Project" prepared by Altındağ Municipality was approved by the board decision dated 3/10/2007 and numbered 62. In line with the projects mentioned, the applications were completed in 2009. 

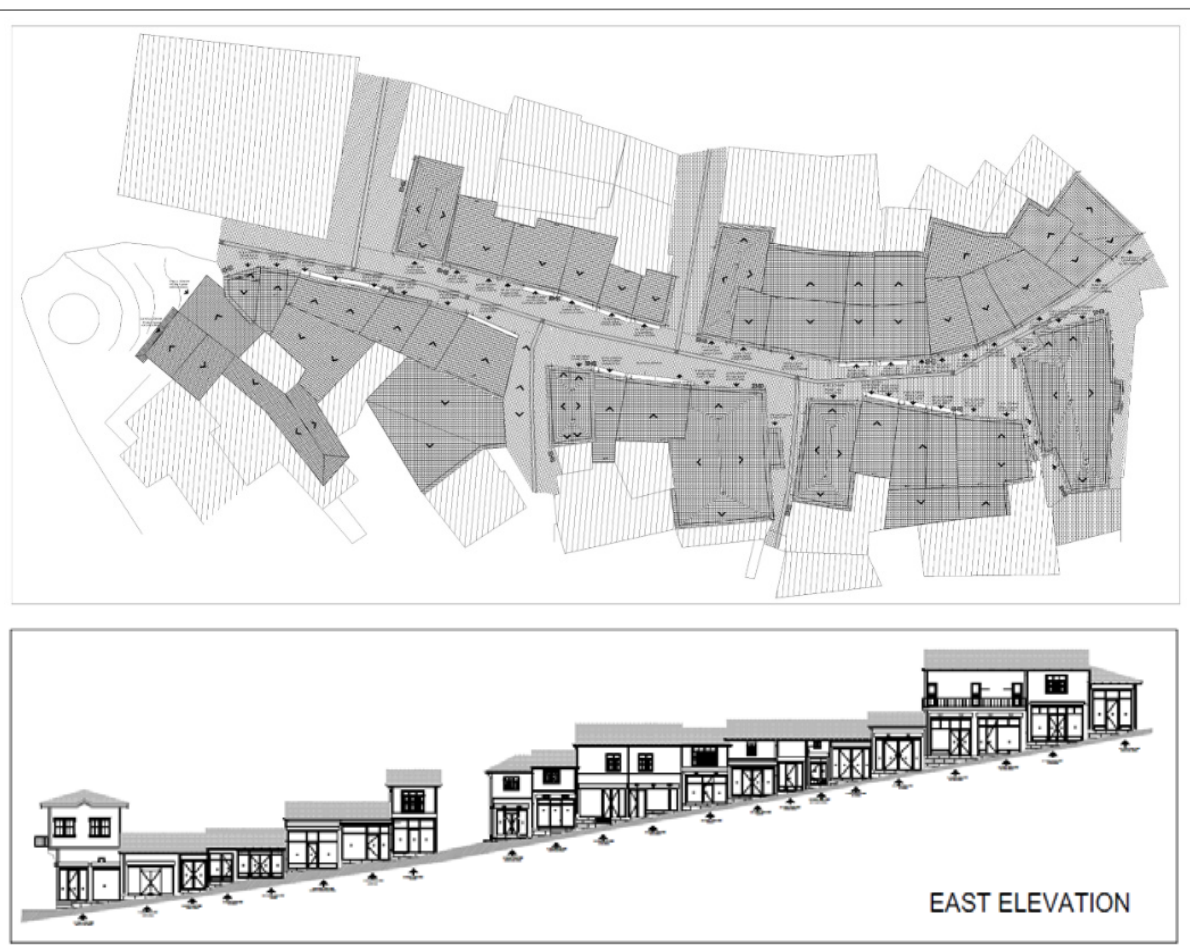

The "Dışkale" (Outer Fortress) was tendered in 2011 in the form of 4 stages within the scope of Ankara Outer Castle and Inner Castle Street Rehabilitation Projects. Both the projects and applications of this stage have been completed. In The Inner Castle, stage 1 projects were completed and the application tender was held at the beginning of 2020 . Projects are also in the tender stage for stage 2 .

The Zoning Plan for The Protection of The Altındağ Renewal Area was canceled by the decision of the Council of Ministers on 21/01/2010 and numbered 2010/88. Therefore, the applications made in the area are carried out according to the Urban Site Transition Period Protection Principles. As for the new Conservation Development Plan works, there has been no progress yet.

\section{SEQUENTIAL TIME SURVEY OF SPACE UTILIZATION IN KOYUNPAZARI SLOPE}

Koyunpazarı Slope and Atpazarı Square are in an important position on the pedestrian road starting from Ulucanlar Street and Hergelen Square, reaching the Kale Gate from Kurşunlu Mosque- Ahi Elvan Mosque and Koyunpazarı Slope (Figure 9-10).

Koyunpazarı Slope joins with Can Street in the south and rises towards the north with a slope of about 7 percent. The structure and environmental character of Pirinç Street, Hanımlar Street, Karakaş Street, Asker Street, Kuş Street, Sefa Street and Arı Street, which is perpendicular to Koyunpazarı Street, are similar. However, the wide-floored and fourstorey buildings at the end of these streets opening to Can Street disrupt the character of the environment (Urak, 1999).
Figure 8. Koyunpazarı Street Rehabilitation Project, site plan and eastern view (Archive of Mimor Architecture Office) 
Figure 9. General view from Koyunpazarı Street (towards Ahi Elvan Mosque) (Karakuș, 2020; Urak, 1998)

Figure 10. View of Çukurhan and the Castle from Atpazarı Square (Karakuş,2020)
Changes and Problems of Conservation in Ankara-Ulus Historical City Center: Koyunpazarı Slope and Atpazarı Square
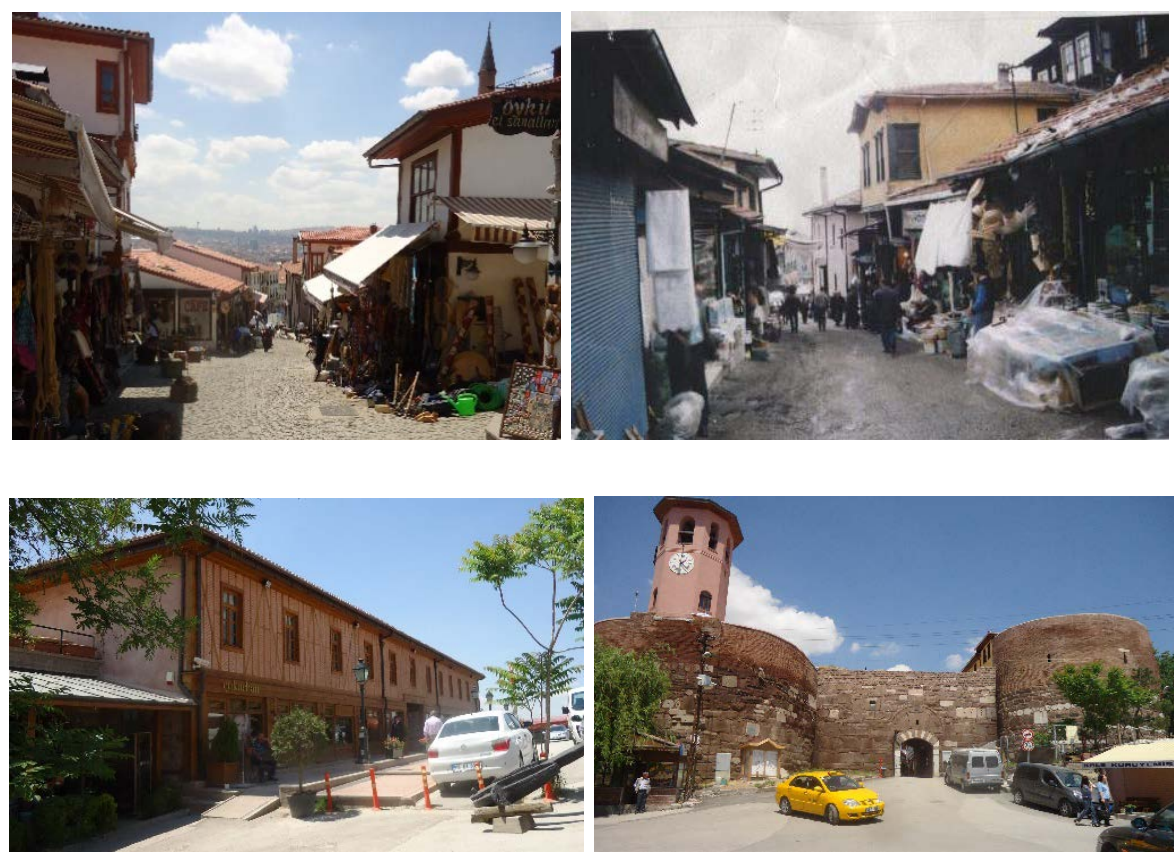

Although only the lower floors of the units 2, 19, 28 and 36, which were residential in 1998, were converted into shops at that time and the upper floors preserved their original character, in the examination carried out in 2020 it was seen that only the upper floor of the unit number 28 was used as a residence, but it was not used after the fire that occurred two years before in the upper floor. It has been determined that the accommodation function is continued on the upper floor of Bala Han number 2 (Figure 11), but the house part has been converted into a cafe. These structures constitute important focal points in the area. The building numbered 36 (Figure 12) also presents a beautiful view while approaching the Koyunpazarı Slope from Ulucanlar. Building no. 19 (Figure 12), which gives the most beautiful view while climbing from Koyunpazarı Slope to Atpazarı Square, is structurally in a very bad condition, and the teahouse on the upper floor could not maintain its function and has turned into a warehouse.

Ahi Elvan Mosque on Koyunpazarı Slope, Hacı Arap Mosque (Figure 13) and Pilavoğluhan, Çukurhan and Çengelhan facing the Atpazarı Square are historical buildings of monumental scale. The fountains in Atpazarı Square and Koyunpazarı Square are valuable environmental elements of these squares.

In a study conducted by Ayşe Tekel, Aybike Ceylan Kızıltaş and Sara Afrher, a test was applied to a certain number of participants to determine whether there was a difference between participants' aesthetic reactions to Ankara's three streets with different characteristics. According to this test, it was seen that the traditional "Koyunpazarı Street" was perceived more positively than other streets. Within the scope of the study, aesthetic reaction variables were found that made this street more positive. Accordingly, "Importance", "Order", 
"Care", "Pleasure", "Arousal", "Rhyme", "Pattern" and "Harmonic Relations" were found to be the variables that most and positively affected the satisfaction of Koyunpazarı Street (Tekel et al., 2018). This study shows how impressive the area is still today.
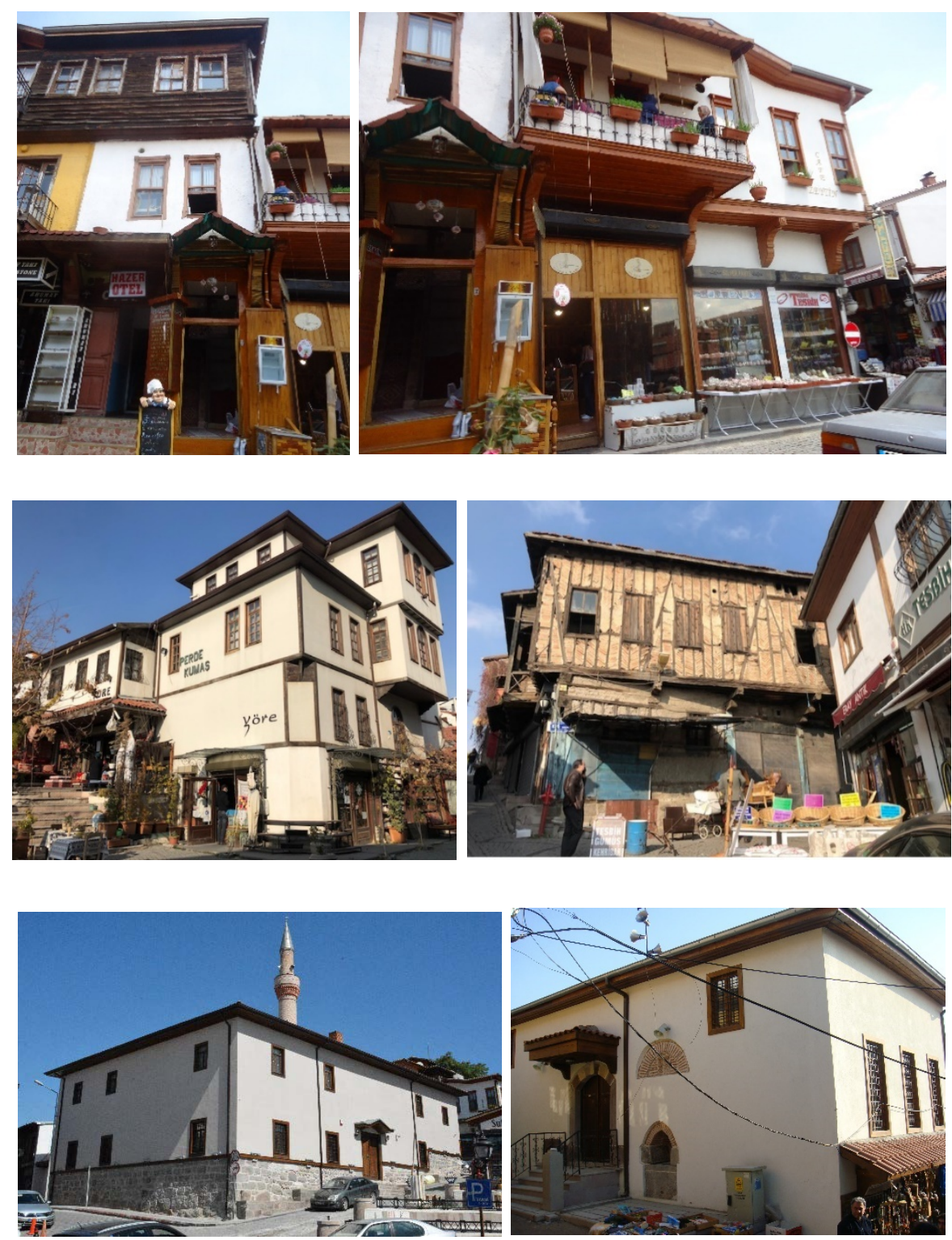

Among the 37 buildings shown in Figure 3 on the street where there is mostly commercial use, buildings 1 (Ahi Elvan Mosque), 2 (Balahan), 16 (Çengelhan), 17 (Çukurhan), 18 (Pilavoğlu Han), 19, 27 and 28 are registered. Within the scope of this study, as in the study conducted in 1998, Çengelhan and Çukurhan were separated from other buildings and evaluated within themselves.

The number of 37 building units on the street has not changed in the intervening twenty-two years. But, while the number of sub-units was 118 in 1998, 115 sub-units were identified in 2020. From these sub-units, numbers 5 and 5A on Can Street, numbers 18 and 20, 28 and 28A, 30 and $30 \mathrm{~A}, 32$ and 34, 75 and 75A, 83 and 85, 87 and 89, 99 and 101 on
Figure 11. Pirinç Street Number 2 (Bala Han) (Karakuş, 2020)

Figure 12. Building numbered 36 in Can Street and building numbered 19 in Koyunpazarı Street (Karakuş, 2020)

Figure 13. Ahi Elvan Mosque and $\mathrm{Hacl}$ Arap Mosque (Karakuş, 2020) 
Changes and Problems of Conservation in Ankara-Ulus Historical City Center: Koyunpazarı Slope and Atpazarı Square

Koyunpazarı Street, 3A and 3B on Hanlar Street, number 76 on Koyunpazarı Street and number 2 in Atpazarı Street were combined and larger shops were created. Also, the numbers 9 and 10, numbers 17 and 18 in Pilavoğlu Han were combined, and the units numbered 1 and 2 were combined with the number 62 . For this reason, the number of sub-units has decreased to 100. The number of sub-units in Çengelhan and Çukurhan, which was 15 in 1998, has been determined as 16 in 2020.

Within the scope of the study, participants were asked questions about the use of space and activity, property structure, occupational execution time, types of transportation used, frequency of purchase of goods, spatial competence, job preference, desire to live in the region, water, electricity, gas-natural gas, toilet, kitchen, sink, heating in commercial units and how the venues were heated.

\section{Space Utilization and Types of Activities in the Area}

In this area, which generally consists of one and two-storey buildings, 13 buildings (35.14\%) are single-storey and 21 (56.76\%) are two-storey. In the area, 2 buildings (5.41\%) are three- storey and 1 building $(2.70 \%)$ is four-storey (Figure 14). There was no change in the number of buildings between 1998-2020, but it was observed that the number of floors of three buildings increased by one. One floor was added to two of the single-storey buildings and one to one of the three-storey buildings.

When 2 mosques and 1 housing were removed from 118 sub-units identified in 1998, 19 (16.52\%) of the remaining 115 sub-units were wholesale shops, $58(50.43 \%)$ retail stores, 4 (3.48\%) workshops, 10 $(8.70 \%)$ hotels, restaurants, tea shops and barbers, 5 (4.35\%) were warehouses and 19 (16.52\%) could not be identified. When 2 mosques have been removed from 100 sub-units in 2020, 3 (3.06\%) of the remaining 98 sub-units are wholesale shops, 33 (33.67\%) are retail stores, 34 (34.69\%) are retail shops with a workshop, 1 (1.02\%) workshop, $10(10.20 \%)$ hotels, restaurants, tea shops and barbers, 9 (9.18\%) warehouses, 2 management units and washbasin, 6 (6.12\%) of them are empty (Figure 15).

In 1998, 6 (40\%) of the shops in Çengelhan and Çukurhan were retail shops, $3(20 \%)$ were hotels, restaurants, tea shops and patisseries, while 6 (40\%) were empty. In 2020, $10(62.50 \%)$ are retail shops, $2(12.50 \%)$ are a hotel and a patisserie, $1(6.25 \%)$ is a museum and $3(18.75 \%)$ are administrative units. 


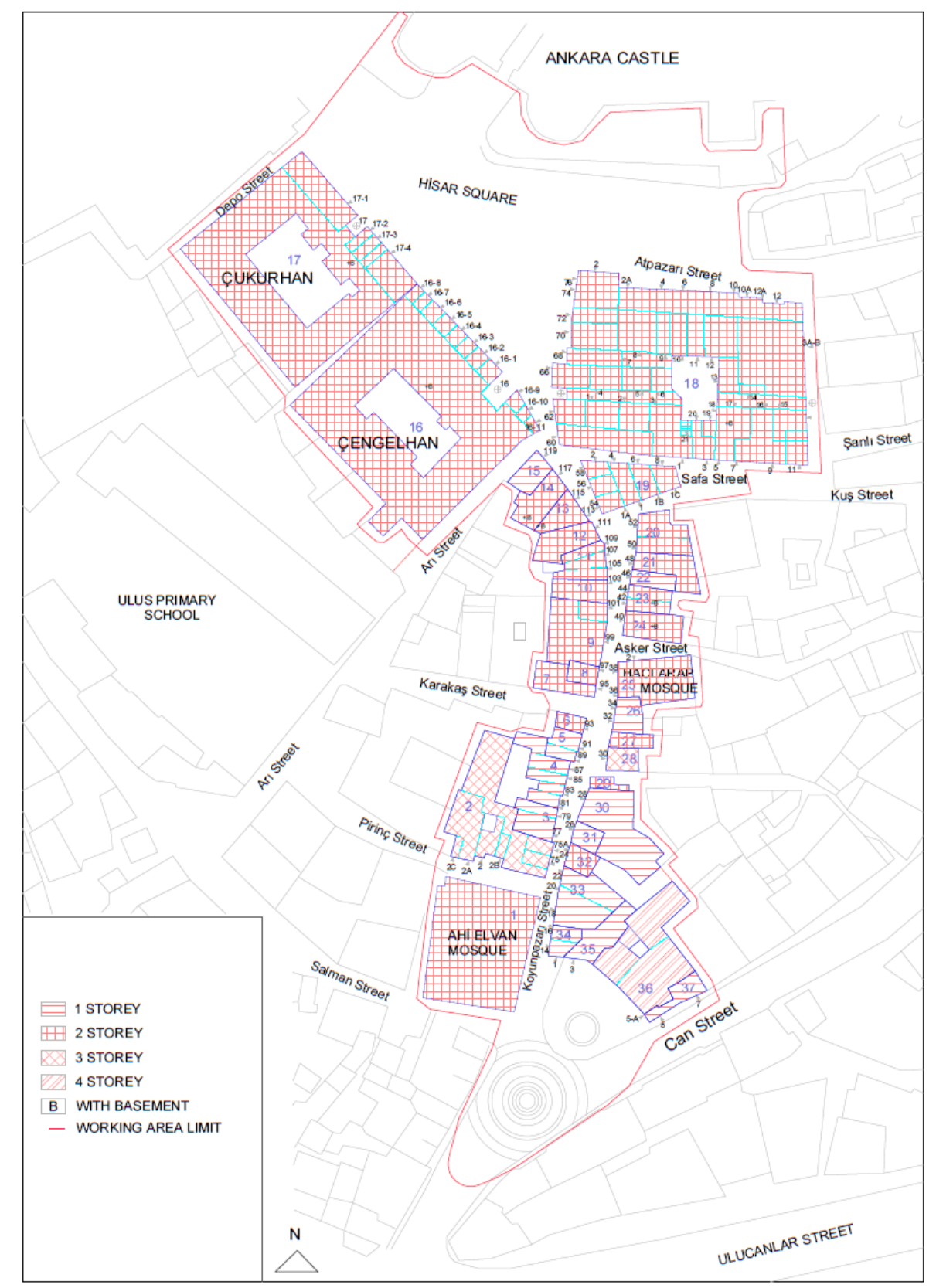

Koyunpazarı Slope still maintains its feature of being a lively commercial street, although not as much as before. It has been observed that there have been serious changes in the types of activities in the area in the meantime (Figure 16-17). The number of saddlery (raw leather), which was $15(12.71 \%)$ in 1998, dropped to zero in 2020. Thus, raw leather warehouses and truck transportation that threaten the building and human health have moved away from the region. The number of shops (29.66\%) engaged in original activities in the area (basket shop, chest shop, hardware store, spice shop, etc.) decreased from 35 to 10 (10\%). The number of haberdashery stores, drapery shops and wool shops has also decreased from $18(15.25 \%)$ to $10(10 \%)$. Among the newly emerged activities, the number of metal scrap dealers, framers, drum repairers, tent-umbrella manufacturing and wedding, henna material makers is 5
Figure 14. Analysis of number of floors (Karakuş, 2020) 
Changes and Problems of Conservation in Ankara-Ulus Historical City Center: Koyunpazarı Slope and Atpazarı Square

(5\%). Warehouses are now used for legumes, dried nuts and fruits, sacks and ready-made wool, and their number has increased from $6(5.08 \%)$ to $9(9 \%)$. The number of shops that are vacant or whose activities are not known in the area under investigation decreased from 12 (10.17) to 6 (6\%). The most important change in the types of activities in the area is the giftware (tile, ceramic, etc.), jewelry design, silver, rosary, painting, artificial flower, mosaic and jewelry design workshops that were not available in 1998. The workshops that started to operate in Pilavoğlu Han have been a positive development for both the inn and Koyunpazarı Street. The number of gift shops and workshops operating in the area is $34(34 \%)$ and 1 unit is used as an executive office and 1 unit is used as a WC in Pilavoğlu Inn.

Figure 15. Commercial unit space utilization
Figure 16. Types of activities in the area

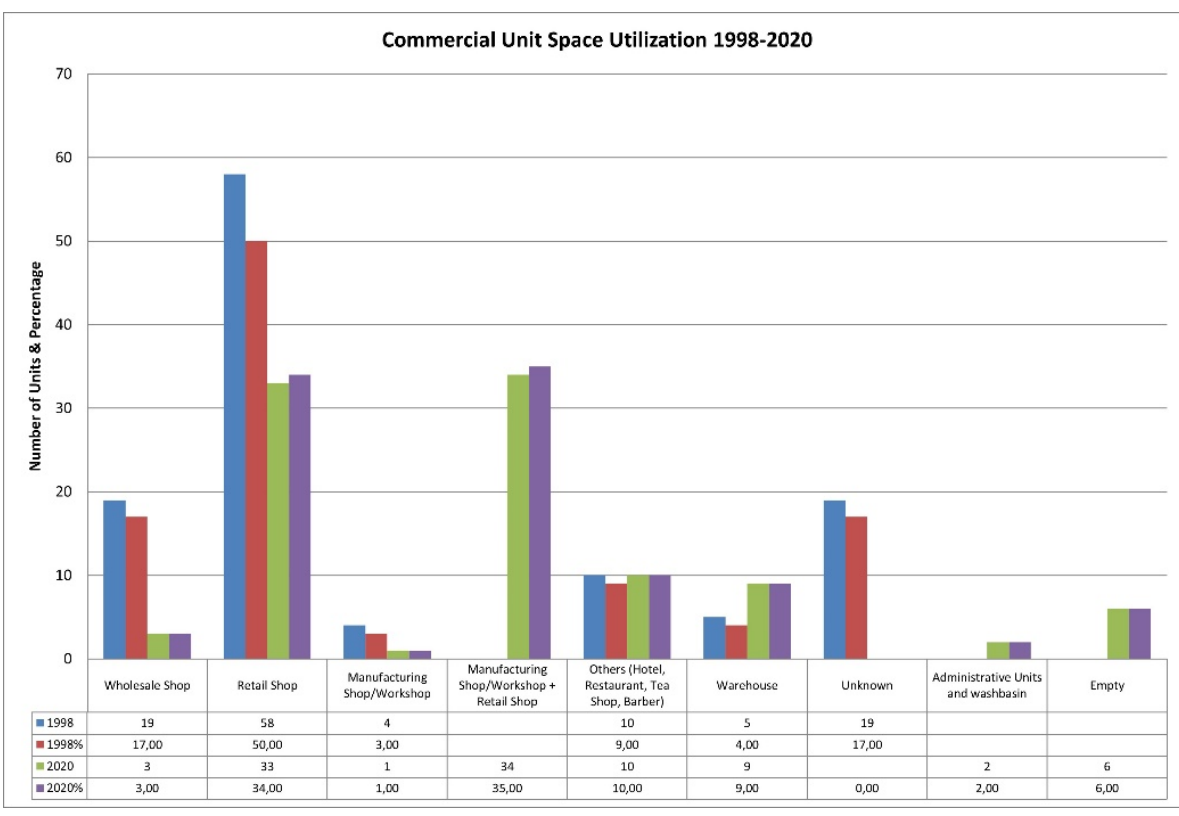




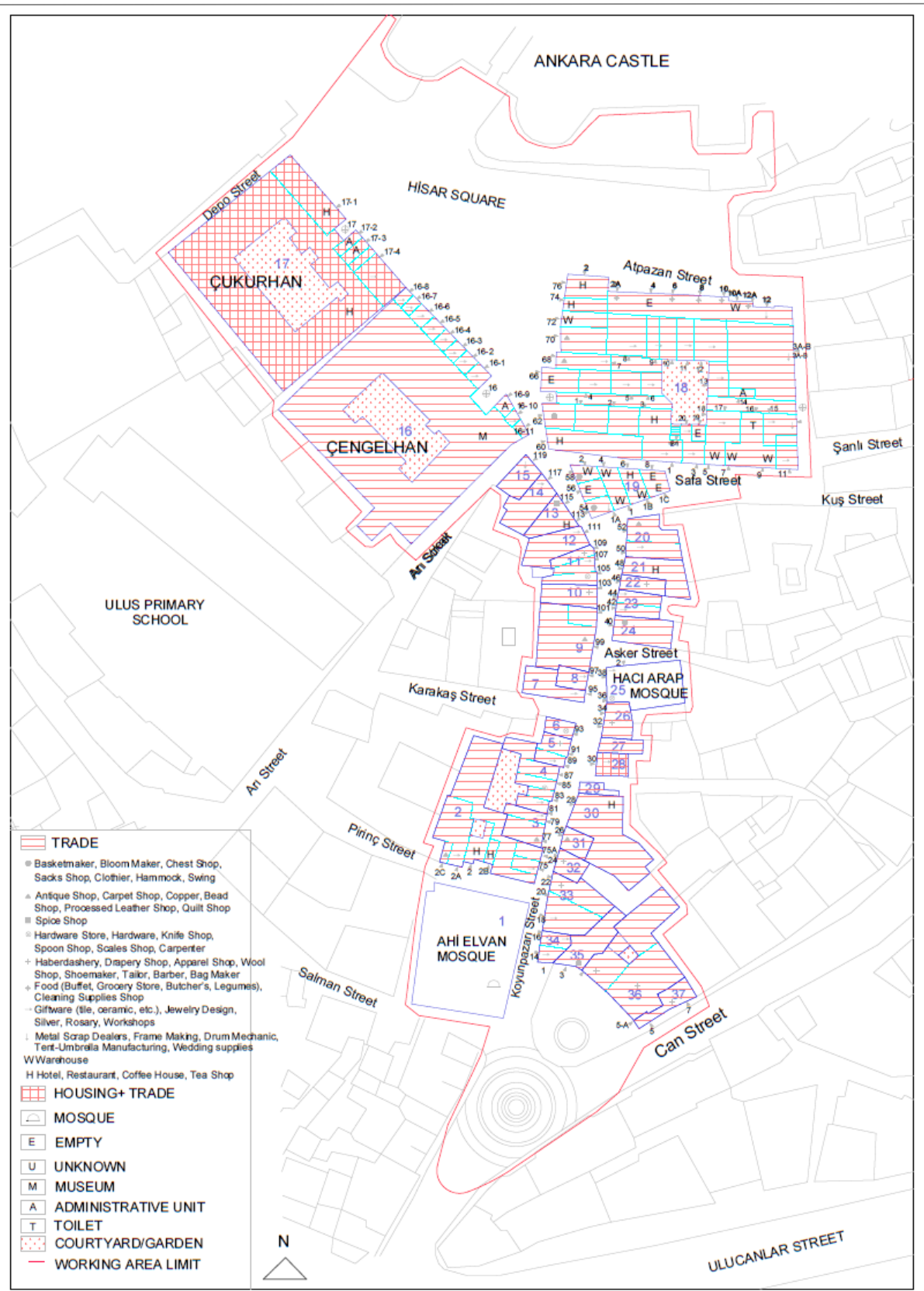

In Çengelhan and Çukurhan, the food and hardware functions were prevalent in 1998 however, we do not see these functions in 2020. When we look at the year 2020, the main function in Cengelhan is the museum and the hotel function in Çukurhan. In addition, there is also a patisserierestaurant in Çukurhan. Apart from this, we see that 7 of the units (43.75\%) are souvenirs, jewelery shops, $1(6.25 \%)$ is a shop selling olive and olive products, $2(12.50 \%)$ are shops selling paintings and ceramic objects and the other 3 units (18.75\%) are used as museums and administrative offices belonging to the hotel.

\section{Ownership Status in Commercial Units}

Ownership status, market and environmental relations, infrastructure conditions, transportation and qualification conditions have been
Figure 17. Analysis of space utilization-Types of Activities (Karakuș, 2020) 
Changes and Problems of Conservation in Ankara-Ulus Historical City Center: Koyunpazarı Slope and Atpazarı Square

examined in 81 actively used sub-units (excluding empty and storage rooms). While 53\% (53 sub-units) of the workplaces in Koyunpazarı Slope were tenants in 1998, the rate of tenants increased to $82.72 \%$ (67 sub-units) in 2020 and in the intervening period, the property ownership has dropped from $43 \%$ to $17.28 \%$ (14 sub-units) (Figure 18). In the period after 1998, all of Çengelhan and Çukurhan became the property of the General Directorate of Foundations and were put into use. The expropriation procedures in the parcels in front of Çengelhan were completed. The mentioned inns were rented for 49 years under the Restore-Operate-Transfer model. For this reason, all units in the inns are tenants. Likewise, in Pilavoğlu Han, all the shops in it have been rented by the owner.

Figure 18. Types of activities in the area

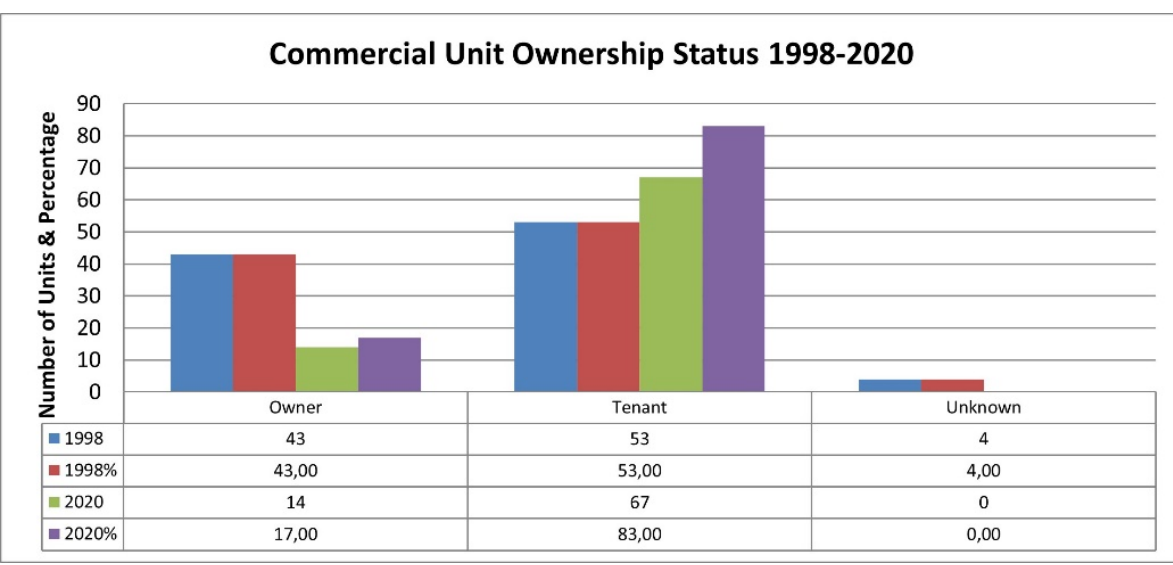

When the ownership status and activity types are compared, it is observed that the owners are mostly engaged in activities such as haberdashery, drapery, apparel, shoemaker and tailorship, secondly wicker basket maker and sack maker; it is understood that the tenants are mostly engaged in activities such as souvenirs (tiles, ceramics, etc.), jewelry design, silversmiths and rosaries. As a result of the policies followed in the area, it has been observed that the gastronomic and touristic goods trade activities for the tourist population have increased gradually. In Çengelhan, activities such as giftware, handicrafts, jewelry design are predominant in the shops outside the museum function of the main building. In Çukurhan, the most important function apart from the hotel function is the patisserie (Divan Patisserie) function. In addition, souvenirs are sold in 3 shops.

Looking at the profession execution time of the business owners in Koyunpazarı Slope, the rate of those who have been operating in the area for more than ten years has decreased from $65 \%$ (65 workplaces) to $45.68 \%$ (37 workplaces). The rate of those who have been operating for less than ten years has increased from 21\% (21 workplaces) to $54.32 \%$ (44 workplaces) (Figure 19). When the profession execution time and the ownership status are compared, it has been determined that the owners who have been working for more than 30 years are more than the tenants, and the tenants who have been working for less than 10 years 
are more than the owners. It has been observed that the tenants in Çengelhan have been operating since 2005, when the inn began to operate, and they have been operating in Çukurhan since 2010. The reason why there are no shops operating longer is that the inns have been completely emptied and rented out through restore-operate-transfer method.

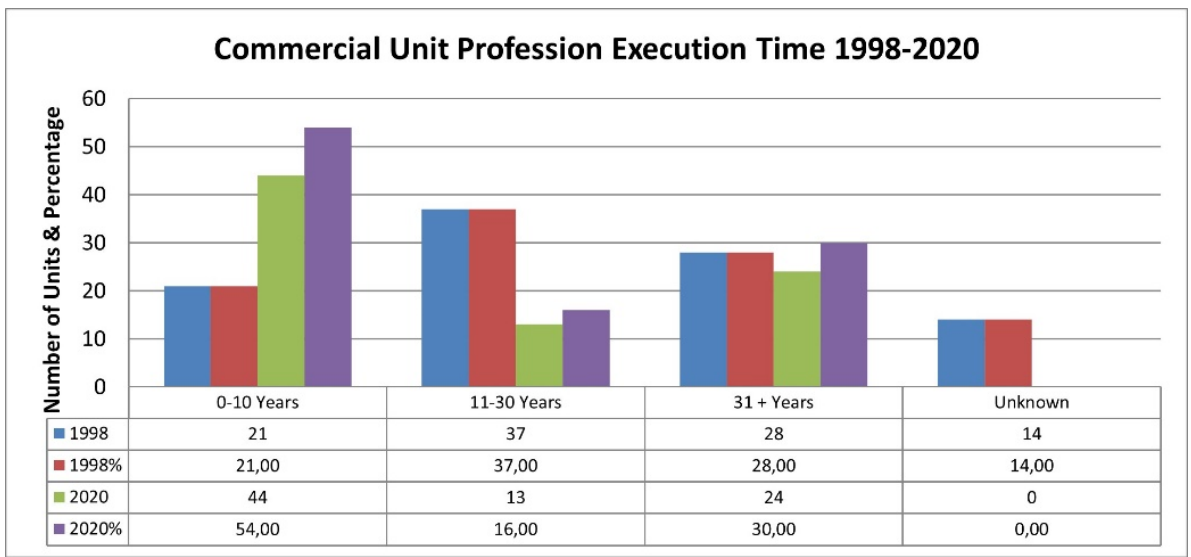

Market and Environmental Relations and Types of Transportation in Commercial Units

When the relationships between the activities in the Koyunpazarı Slope and immediate vicinity and inner and outer parts of Ankara have been examined, it has been seen that there are no tradesmen buyers outside Ankara except for the tourists who come to buy the goods sold and produced in this area. Depending on the types of goods sold, local people and mostly local and foreign tourists stand out among the buyer groups. In the intervening time, the rate of shipping the goods of workplaces located on Koyunpazarı Slope by truck decreased from 50\% (50 workplaces) to $16.05 \%$ (13 workplaces). In parallel with this decrease, the rates of shipping by automobile and van have increased. 53.09\% (43 units) of the workplaces transport their goods by automobile, 29.63\% (24 units) transport their goods by van or cargo (Figure 20). This is due to the changes in the works and types of activities in the area. In addition, the decrease in the frequency of daily purchases from $13.00 \%$ to $9.88 \%$ (Figure 21) has reduced the negative effects of vehicles in the area. It has been determined that almost all (91.67\%) of the shops in Çengelhan and Çukurhan bring their goods through cargo companies.

In Koyunpazarı Slope, the rate of business owners who find the space of their commercial units sufficient was $52 \%$ in 1998 , while this rate is $79.01 \%$ in 2020 (Figure 22). This increase in the adequacy ratio has appeared due to the combination of sub-units and the decrease in the use of areas such as wholesalers and workshops. In Çukurhan and Çengelhan, the rate of those who find their space sufficient is $81.82 \%$, and the rate of those who do not find it sufficient is $18(18 \%)$.
Figure 19. Commercial Unit Profession Execution Time 
Figure 20. Shipping in Commercial Units

Figure 21. Commercial Unit frequency of purchasing goods

Figure 22. Commercial Unit Spatial Adequacy
Changes and Problems of Conservation in Ankara-Ulus Historical City Center: Koyunpazarı Slope and Atpazarı Square
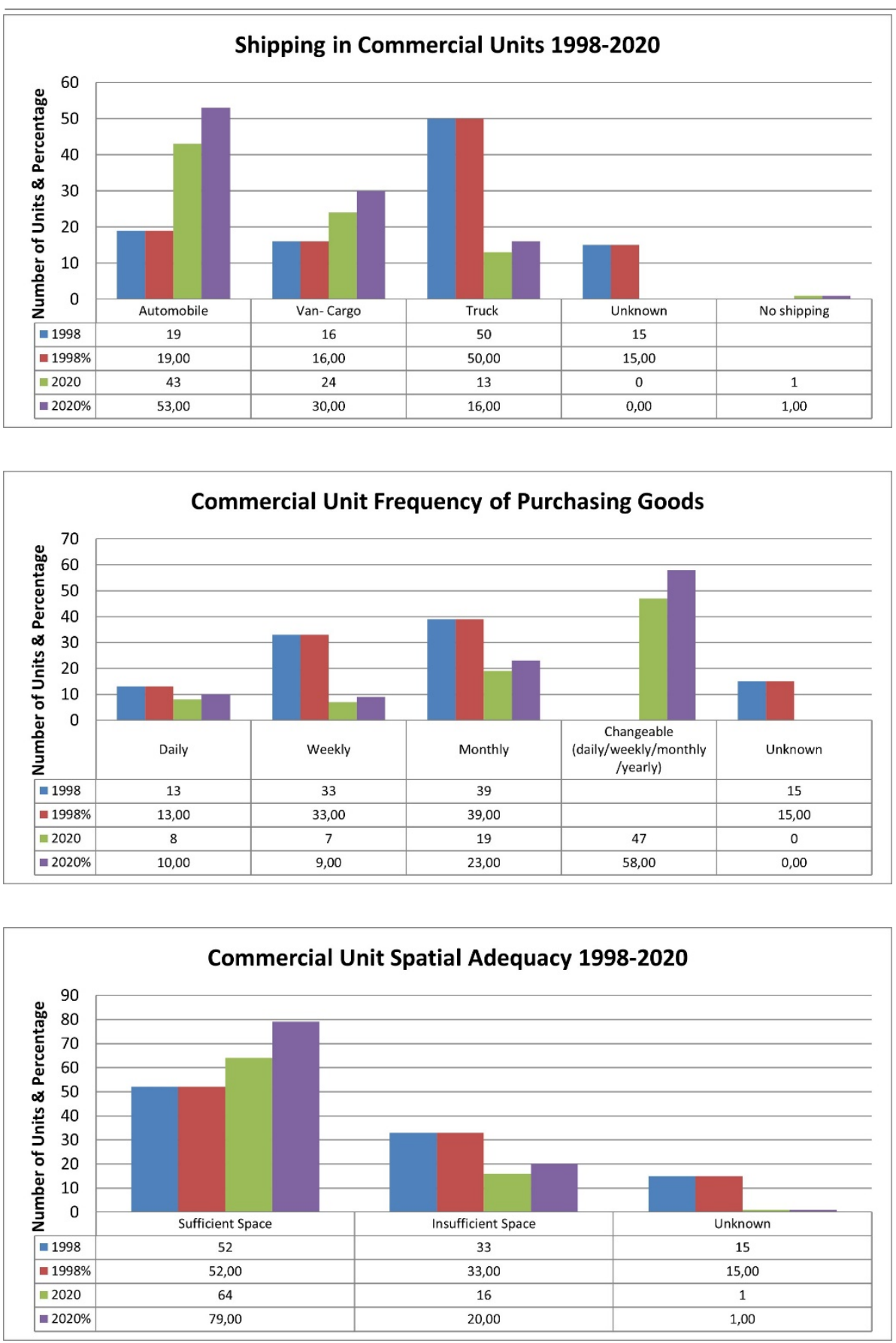

Those who want to continue their current activities in Koyunpazarı Slope (Figure 23) are in the majority with a ratio of $71.60 \%$ (58 workplaces). The reason why this rate decreased from $78 \%$ to $71.60 \%$ between 1998 and 2020 can be attributed to the fact that people find the products and materials they seek more comfortably in the shopping malls built recently. The rate of those who want to continue the same activity is the majority in Çengelhan (same type of activity 100\%). 


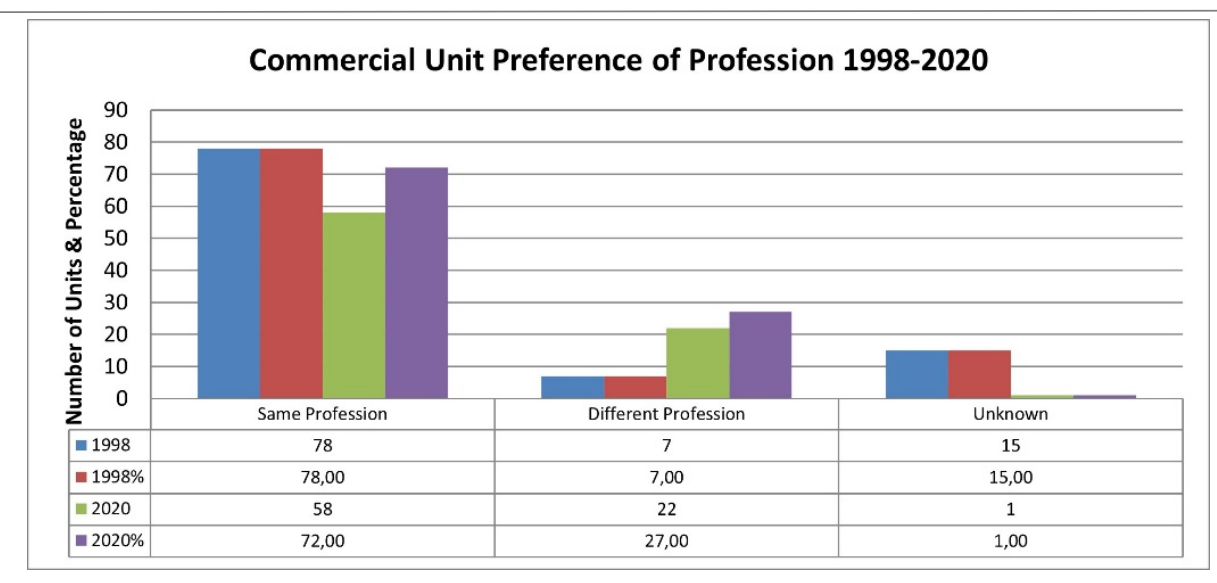

The desire of the operators in Koyunpazarı Slope to reside in the region has decreased from $38 \%$ to $19.75 \%$ within twenty-two years (Figure 24 ). This rate has changed from $20 \%$ to $18.18 \%$ for the operators in Çengelhan. It is thought that this decrease in the rates is due to the decrease in the number of residences in the region, the changes in the number and quality of the visitors of the region and the desire of the operators to live in the more expensive districts of Ankara.

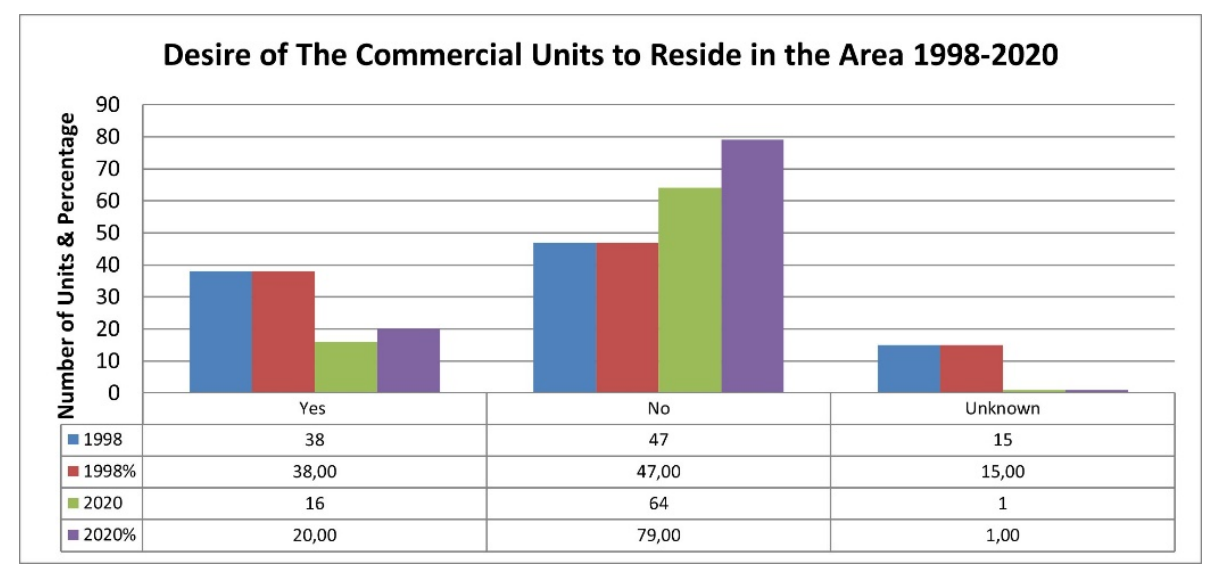

\section{Physical Condition of Buildings and Infrastructure and Health Conditions in the Area}

Considering the status of the buildings in the area, the percentage of buildings in good condition increased from $32.43 \%$ to $91.89 \%$ (Figure 25). Çengelhan and Çukurhan were repaired within the scope of the restore-operate-transfer tender held by the General Directorate of Foundations, Ahi Elvan Mosque was repaired in 2017, Hacl Arap Mosque was repaired in 2007 and Koyunpazarı Street Rehabilitation works were completed in 2009. However, Pilavoğlu Han and the building at the intersection of Koyunpazarı Street and Safa Street, two important buildings in the area, are still structurally in poor condition (Figure 26).
Figure 23. Commercial Unit Preference of Profession

Figure 24. Desire of the commercial units to reside in the region 
Figure 25. Physical condition of the structures

Figure 26. Pilavoğlu Han and the building at the intersection of Koyunpazarı Street and Safa Street (Karakuş, 2020)
Changes and Problems of Conservation in Ankara-Ulus Historical City Center: Koyunpazarı Slope and Atpazarı Square
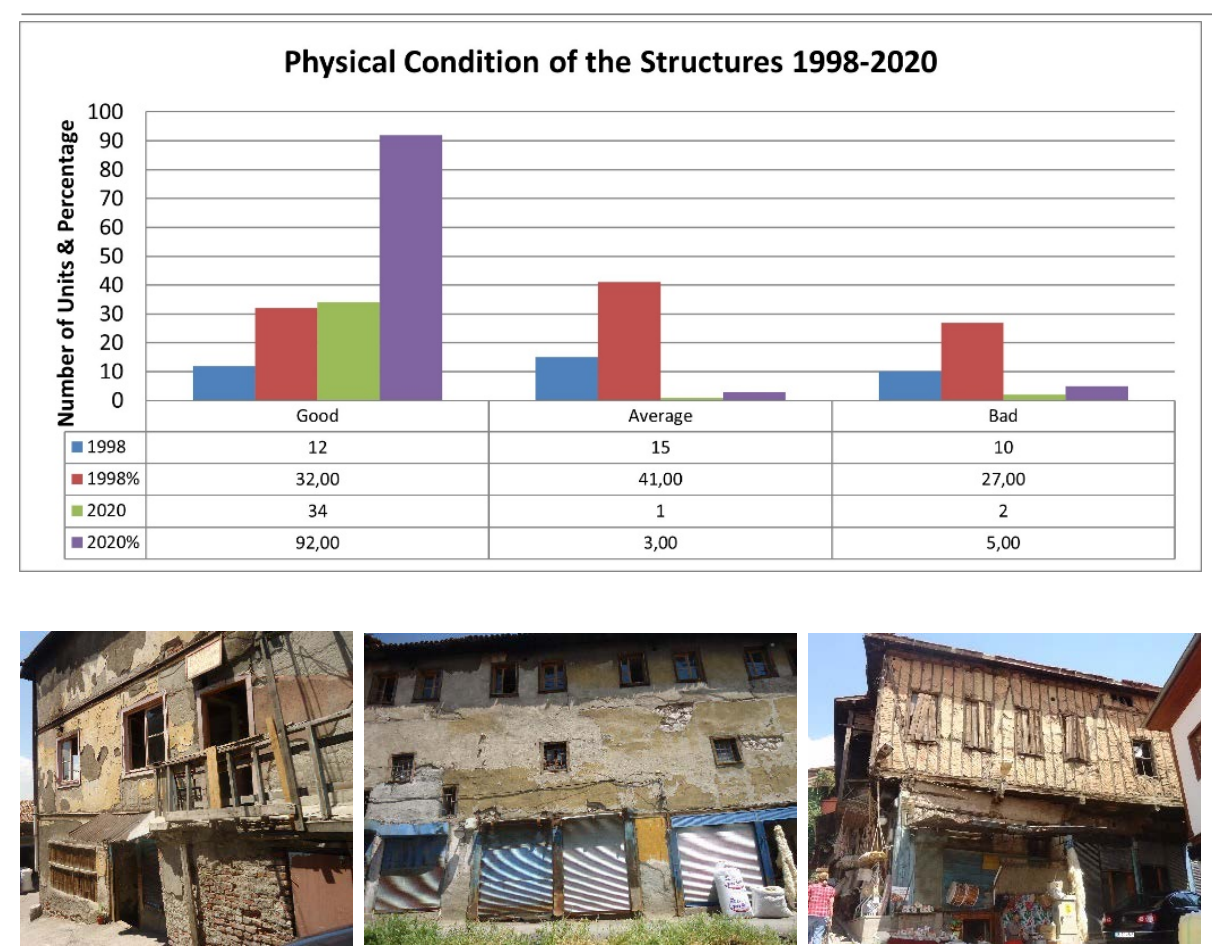

Infrastructure services that are directly related to health conditions such as water, electricity, natural gas, toilet, kitchen, washbasin and heating create a very negative picture in the work area. Although there is a sewerage connection in the area, only $23.46 \%$ of the units have water connection and the majority $(75.31 \%)$ do not have a water connection. Toilets and washbasins are often not available due to the lack of water. The working population in the area generally uses the public toilets adjacent to Ahi Elvan Mosque. Inside the Pilavoğlu Han, there is a public lavatory and toilet area used by the employees of the inn. All units have electricity, except for 1 workplace. There is no central heating except one of the units in the street, which has no coal gas or natural gas connection, but Çengelhan and Çukurhan have a natural gas connection and underfloor heating is provided. 49 (60.49\%) workplaces in the area are heated by electric heaters and $24(29.63 \%)$ workplaces are heated by stoves. Besides, there is no heating in $1(1.23 \%)$ workplace. The kitchen is only available in workplaces where it is needed such as in kebab restaurants, restaurants, tea shops, and cafes. The insufficiencies in health conditions continue in the same way (Figure 27). 

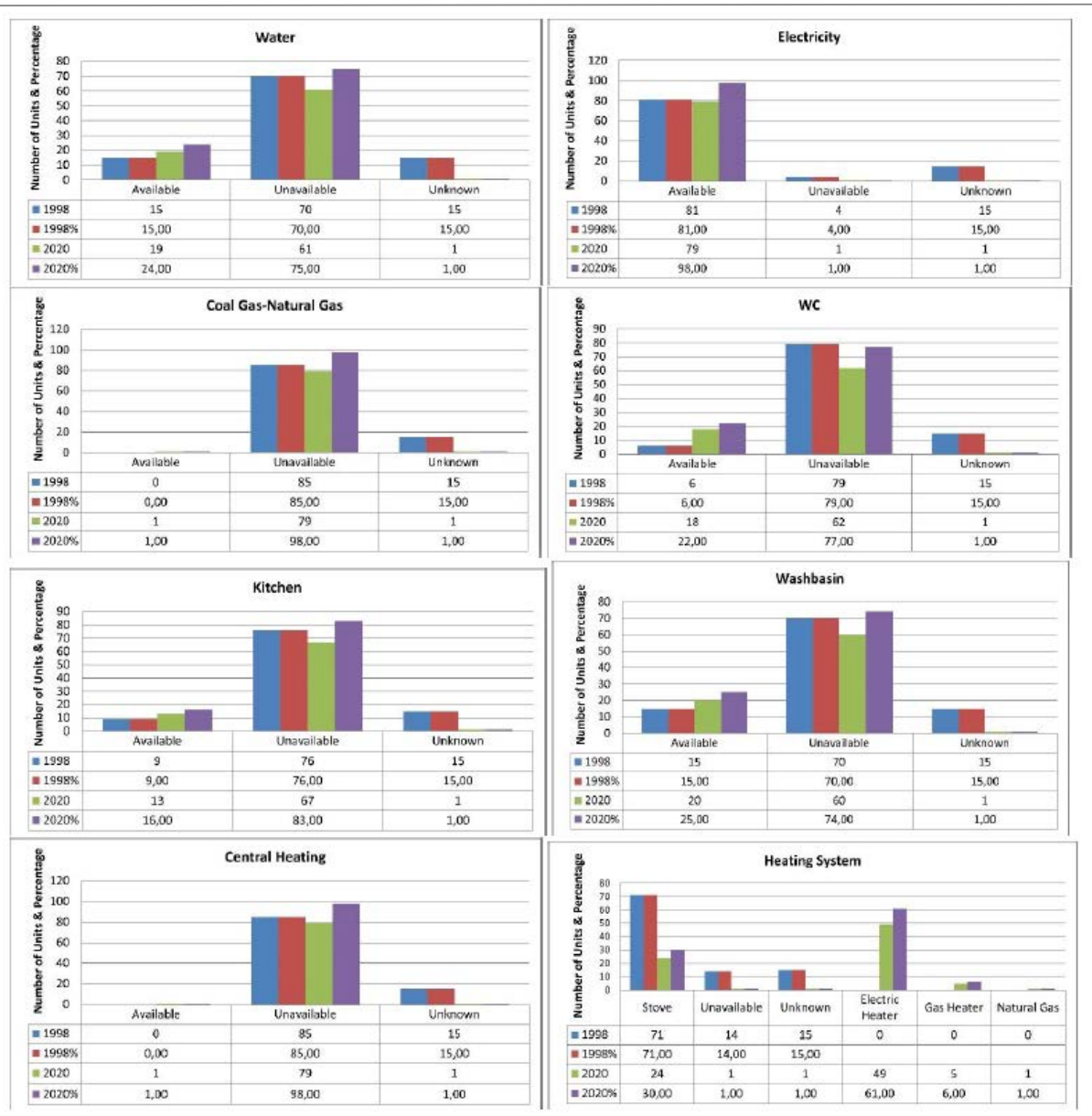

Figure 27. Commercial unit health and infrastructure conditions

\section{EVALUATION OF RESEARCH RESULTS}

The evaluation made as a result of the consecutive researches of the use of spaces in Koyunpazarı Slope and Atpazarı Square are gathered under the titles of physical conditions, social-functional conditions and infrastructure conditions.

\section{Physical conditions:}

- It has been observed that the number of buildings (37) in the area did not change during the intervening period, but two floors were added to two of the single-storey buildings and one to one of the three-storey buildings. Since the 1990s, various project studies have been carried out for the conservation of the area, but although they have not been implemented, these studies have drawn attention to the importance of the field and prevented significant physical changes in the field.

- Among the buildings in the area, Çengelhan, Çukurhan, Ahi Elvan Mosque and Hacl Arap Mosque have been repaired by the General Directorate of Foundations. Koyunpazarı Street Rehabilitation works were completed in 2009. For this reason, the structures in the area are in good physical condition to a great extent. However, Pilavoğlu Han and the building at the intersection of Koyunpazarı Street and Safa Street are in urgent need of repair. The completion and implementation of the project works in the inner and outer castle, which are closely related to the area, 
Changes and Problems of Conservation in Ankara-Ulus Historical City Center: Koyunpazarı Slope and Atpazarı Square

is also one of the positive developments regarding the area. However, it was also observed that a sustainable and integrated protection was not created in the area, and the works were limited to individual restorations and street rehabilitation works.

- In the intervening twenty-two years, the rate of trucking the goods of the workplaces in the area has decreased significantly. In proportion to this decrease, the rates of transportation by automobile, van and cargo increased. This situation arises from the change in activity types in the field (with the complete abolition of saddlery and the decrease in the number of wholesalers). In addition, the change in the frequency of buying goods by the workplaces operating in the field has also reduced the complexity and visual pollution caused by the vehicles.

- The reason for the increase in the rate of those who find commercial unit areas sufficient among the business owners in the workplace is that some workplaces are used by combining sub-units, as well as the decrease in workplaces that need more space such as wholesalers and workshops.

\section{Social-functional conditions:}

- In the study on the use of space, it has been observed that the ratio of wholesale shops decreased, while retail sales increased. When the activity types in the field have been examined, it has been seen that there have been no more saddlery, which existed in the previous periods, and there has been a serious decrease in the original activities such as hardware store, spice shop, and yarn. It is among the findings that the structures are saved from harmful effects such as the removal of saddlery (raw leather pre-processing mills) from the buildings and the saltyorganic/acidic water that comes out of the sheep skins pressed into salt, causing melting in the brick and stone texture and threatening the carrier system. The most important change in the activity types in the field is the existence of souvenir shops (china, ceramics, etc.), jewelry and silver shops and painting, mosaic and jewelry design workshops that were not in 1998. On the basis of these changes in the field, it has been observed that activities for cultural tourism, which have gained weight in recent years, have been taking place, and as a result of the policies followed, commercial units engaged in the trade of gastronomic and touristic goods for the tourist population have increased gradually. After the resolution of the property problems of Çengelhan and Çukurhan, the museum and hotel functions assigned to the buildings are also functions determined for tourism.

- When the ownership structure of the commercial units in the area has been examined, it has seen that the rate of tenants has increased. This is due to the fact that the former property owners, who continued their original activities in the field, preferred to lease their workplaces due to their difficulties in continuing the old activities. In the period after 1998, the ownership of Çengelhan and Çukurhan has been transferred to the General Directorate of Foundations and all the workplaces in these 
buildings are in the position of tenants since the buildings have been rented out by the restoration-operate-transfer method.

- When the duration of the profession of the business owners in the field is examined, it has seen that the rate of those who have been active in the field for more than ten years has decreased, and the rate of those who have been operating for less than ten years has increased. It has been observed that this situation has developed as a result of the changes in the activity types in the field and the former operators leaving their places to the new ones.

- In the Koyunpazarı Slope, the desire of the operators to sit in the region has decreased considerably in the intervening period. This decrease is based on the decrease in the number of residences in the region, the region staying in the poor part of the city and the difficulties experienced in adapting the traditional houses located near the area to today's needs.

\section{Infrastructure conditions:}

- The most important problem seen in the field is related to health and infrastructure conditions. Although there is a sewer connection in the area, most of the units do not have a water connection. Consequently, most workplaces do not have toilets and sinks. The population working in the area generally uses the public toilets near the Ahi Elvan Mosque. Inside the Pilavoğlu Han, there is a general lavatory and toilet area that the employees of the inn can use. In the street, which does not have gas and natural gas connections, there is only a heating system at number 60 , and electrical heaters are used in other units. In Çengelhan and Çukurhan, there is a natural gas connection and underfloor heating is provided.

\section{CONCLUSION}

There has been a significant change of function in the shops located on one of these oldest commercial streets of Ankara. However, the speed of change is a parameter that needs to be controlled, and excessive rapid change can adversely affect the integrity of the values of a historic city. The size and frequency of interventions should be based on feasibility studies and should be in line with plan decisions. The preservation of a historic city requires efforts to maintain traditional arts and activities. New events should be carefully selected to prevent secondary adverse effects such as transportation/transport problems or traffic jams (ICOMOS, 2011, Valetta Principles). For this purpose, care should be taken to protect some shops (food, hardware stores, spice store, etc.) that continue their old functions. Changes in the fields of activity should be controlled and a planning work should be carried out in this area.

All interventions in historical cities and urban areas should respect their abstract and concrete cultural values. Every intervention in historical cities and areas should aim to improve the quality of life and the nature of the environment of the inhabitants (ICOMOS, 2011, Valetta Principles). The relevant municipalities and institutions should urgently bring a solution to the infrastructure problems identified in the area and the 
Changes and Problems of Conservation in Ankara-Ulus Historical City Center: Koyunpazarı Slope and Atpazarı Square

health conditions in the area should be improved. It should be ensured that the traditional residences around the area are made suitable for today's comfort conditions. In addition, an integrated protection policy that will include the commercial area subject to the research and the surrounding residential area should be developed.

The conservation zoning plan prepared for Altındağ Region (Ulus Historical City Area) should be completed and implemented urgently. For the reconstructions to be carried out in and around the area, the structuration conditions should be determined correctly and decisions should be made by evaluating the success of the new buildings in and around the area. The Protection Plan to be prepared must determine the conditions, rules, objectives and consequences of the change. It should determine which buildings and places should be strictly protected, which will be protected under certain conditions, and which can be overlooked in unusual circumstances. In addition, the plan to be prepared should aim to ensure a harmonious relationship between the historical city areas and the whole city (ICOMOS, 1987, Washington Charter). Before entering any new construction in the aforementioned area or in the immediate vicinity, an urban environmental analysis should be carried out not only to define the general character of the historical settlement, but also to identify the harmony of heights, the colors, materials and forms used, the types of facades and roofs used, the positions of building masses in the parcel, the construction rates in the parcels (ICOMOS, 1976, Nairobi Recommendations).

The structurally poor structures of Pilavoglu Han and building at the intersection of Koyunpazari Street and Safa Street needs to be repaired urgently. In order to carry out repairs in Pilavoglu Han, property problems should be solved and, if necessary, expropriated and the relevant institutions should lead the repair works.

Although the truck entrance has decreased, traffic arrangements should be made in the area and vehicle entry and exit times should be arranged in order to prevent the image and noise pollution created by the vehicles. Accordingly, parking arrangements should be made in a place where the area is easily accessible for those who want to visit the area or come for work to park their vehicles. These studies should be carried out in a way that does not damage the historical texture and its surroundings as stated in the Washington Charter.

The protection of historical cities and urban areas is part of the process of preserving and understanding the city and its environment as a whole and requires consistent, economic and social development policies that address these historical cities at all levels of planning and respect their social textures and cultural diversity. In addition, continuous monitoring and maintenance is mandatory to effectively protect a historic city or urban area. Up-to-date information and data (environmental analysis, history and development phases of the city, etc.) are needed for accurate planning. Since the protection of the historical city or area concerns the residents first, it is necessary to meet with the local people and 
stakeholders, get their opinions and be in constant communication (ICOMOS, 2011, Valetta Principles).

It should be noted that historical cities and urban areas should be part of economic and social development policies and city and region policies at all levels (ICOMOS, 1987, Washington Charter). To achieve a sustainable tourism industry and ensure the transfer of cultural heritage sites to future generations, the participation and cooperation of representatives of local and/or indigenous communities, environmentalists, tourism operators, property owners, policy makers, national development planners and site managers is required. A significant portion of the revenue from tourism programs to heritage sites should be allocated for the protection, preservation and promotion of such venues, including their natural and cultural conditions (ICOMOS,1999, International Cultural Tourism Charter).

These determinations are thought to be guiding for the transfer and preservation and promotion of our cultural heritage in Koyunpazarı Slope and Atpazarı Square in Ankara's Historical City Center. In addition, it is recommended that this work be expanded by taking into other streets surrounding the area and act with a holistic understanding of protection.

\section{ACKNOWLEDGEMENTS/NOTES}

The authors have no acknowledgements or other involvements in this study.

\section{CONFLICT OF INTEREST}

No conflict of interest was declared by the authors.

\section{FINANCIAL DISCLOSURE}

The authors declared that this study has received no financial support.

\section{ETHICS COMMITTEE APPROVAL}

Ethics committee approval was not required for this article.

\section{LEGAL PUBLIC/PRIVATE PERMISSIONS}

In this research, the necessary permissions were obtained from the relevant participants (individuals, institutions and organizations) during the survey, in-depth interview, focus group interview, observation or experiment.

\section{REFERENCES:}

Ahunbay, Z. (1996). Tarihi Çevre Koruma ve Restorasyon, İstanbul: YEM Publication.

Akdağ, M. (1974). Türkiye'nin Íktisadi ve İçtimai Tarihi (1243-1453), v.1, İstanbul: Cem Publication. 
Changes and Problems of Conservation in Ankara-Ulus Historical City Center: Koyunpazarı Slope and Atpazarı Square

Akgül, O. (2003). Turistik Ürün Çeșitlendirmesi Kapsamında Kültür Turizmi, Aphrodisias-Geyre Örneği, [Master's Thesis, Adnan Menderes University, Institute of Social Sciences]. Aydın.

Aksoy, Z. (2010). Kentsel Alanda Vakıf Taşınmazlarının Dönüşümü: Başkentlik Sürecinde Ankara Örneği, [Master's Thesis, Gazi University, Graduate School of Natural and Applied Sciences]. Ankara.

Aktüre, S. (1978). 19. yy sonunda Anadolu Kenti Mekansal Yapı Çözümlemesi, Ankara: METU Faculty of Architecture Publications.

Aktüre, S. (1984). 16. yy öncesi Ankara Üzerine Bilinenler. E. Yavuz and Ü. N. Uğurel. (Editors), Ankara in History September 1981 Seminar Papers. Ankara: METU Faculty of Architecture Publications, 1-47.

Aktüre, S. (2001). Ankara'da Günlük Yaşam. Yıldırım Yavuz (Editor), Ankara in History II. Ankara: METU Faculty of Architecture Publications, 35-74.

Ashurst, J. (2007). Conservation of Ruins, Oxford: ButterworthHeinemann.

Avcıkurt, C. (1997). Avrupa Birliği ile Bütünleșme Sürecinde Türk Turizmi (Sorunlar ve Çözüm Önerileri), [Doctoral Thesis, Balıkesir University, Institute of Social Sciences]. Balıkesir.

Bakırer, Ö. \& Madran, E. (1984). Ankara Kent Merkezinde Özellikle Hanlar ve Bedestenin Ortaya Çıkışı ve Gelişimi, Ankara in History September 1981, Seminar Papers, Ankara: METU Faculty of Architecture Publications, 105-128.

Beyhan, Ş. G. \& Ünügür, S. M. (2005). Çağdaş Gereksinmeler Bağlamında Sürdürülebilir Turizm ve Kimlik modeli, İÜ Journal/A Mimarlık, Planlama, Tasarım, 4(2):79-87.

Biçer, N. B. (2019). An Exploration Of Urban Soundscape in Ulus, Ankara, [Master's Thesis, Middle East Technical University, Graduate School of Natural and Applied Sciences]. Ankara.

Binan, C. (1999). Mimari koruma Alanında Venedik Tüzüğ̈̈nden Günümüze Düşünsel Gelişmenin Ulusla arası Evrim Süreci, İstanbul: YTU Publication.

Council of Europe, Convention for the Protection of the Architectural Heritage of Europe. Council of Europe. Retrieved April 07, 2021, from https://rm.coe.int/CoERMPublicCommonSearchServices/DisplayDCTM Content?documentId=090000168007a087.

Çakır, Z., G., Altınöz, G., B. \& Özüduru, B., H. (2019). Ankara Hanlar Bölgesi'nin Mekansal Gelişimi ve Bugünkü Kullanıcı Profilinin Değerlendirilmesi, Tüba-Ked, 20: 175-201.

Dinç, Z. (2021, May 6). XVI. Yüzyılda Osmanlı Devleti'nde Çarşı'nın Kent Hayatına Etkisi: Ankara Örneği, https://www.academia.edu/3861379/XVI_YÜZYILDA_OSMANLI_DEVLE Tİ_NDE_ÇARŞI_NIN_KENT_HAYATINA_ETKİSİ_ANKARA_ÖRNEĞİ.

Erder, C. (1971). Tarihi Çevre Kaygısl, Ankara: METU Faculty of Architecture Publications. 
Erder, C. (1975). Tarihi Chevre Bilinci, (1st ed.). Ankara: Middle East Technical University Publications.

Ergenç, Ö. (1984). XVI. Yüzyıl Ankara'sı Ekonomik ve Sosyal Yapı ve Kentsel Özellikleri. E. Yavuz and Ü. N. Uğurel. (Editors). Ankara in History September 1981 Seminar Papers, Ankara: METU Faculty of Architecture Publications, 49-61.

Giritlioğlu, İ. \& Avcıkurt, C. (2010). Şehirlerin Bir Turistik Ürün Olarak Pazarlanması, Örnek Şehirler ve Türkiye'deki Şehirler Üzerine Öneriler (Formed from a compilation application). Adiyaman University Journal of Social Sciences Institute, 4, 74-89.

Huh, J. (2002). Tourist Satisfaction with Cultural/Heritage Sites: The Virginia Historic Triangle, [Master's Thesis, The Virginia Polytechnic Institute and State University, Master of Science in Hospitality and Tourism Management]. Virginia.

ICOMOS, Washington Charter. International Council on Monuments and Sites. Retrieved December 19, 2020, from

https://www.icomos.org/charters/towns_e.pdf.

ICOMOS, Athens Charter for the Restoration of Historic Monuments. International Council on Monuments and Sites. Retrieved April 07, 2021, from https://www.icomos.org/en/167-the-athens-charter-for-therestoration-of-historic-monuments.

ICOMOS, Venice Charter, International Council on Monuments and Sites. Retrieved April 07, 2021, from

https://www.icomos.org/charters/venice_e.pdf,

ICOMOS, Amsterdam Declaration. International Council on Monuments and Sites. Retrieved April 07, 2021, from https://www.icomos.org/en/and/169-the-declaration-of-amsterdam.

ICOMOS Austria, Burra Charter. International Council on Monuments and Sites. Retrieved April 07, 2021, from https://australia.icomos.org/publications/burra-charter-practicenotes/burra-charter-archival-documents/\#BC1999.

ICOMOS, Charter for the Conservation of Historic Towns and Urban Areas Washington Charter. International Council on Monuments and Sites. Retrieved April 07, 2021, from https://www.icomos.org/charters/towns_e.pdf.

ICOMOS, Nara Certificate of Authenticity. International Council on Monuments and Sites. Retrieved April 07, 2021, from https://www.icomos.org/charters/nara-e.pdf.

ICOMOS, International Cultural Tourism Charter: Managing Tourism at Places of Heritage Significance. International Council on Monuments and Sites. Retrieved May 06, 2021, from https://www.icomos.org/charters/tourism_e.pdf.

ICOMOS, The Valletta Principles for the Safeguarding and Management of Historic Cities, Towns and Urban Areas. International Council on Monuments and Sites. Retrieved May 06, 2021, from http://www.icomos.org.tr/Dosyalar/ICOMOSTR_en059303400153691 2260.pdf. 
Changes and Problems of Conservation in Ankara-Ulus Historical City Center: Koyunpazarı Slope and Atpazarı Square

Jokilehto, J. (1999). A History of Architectural Conservation, Oxford: Elsevier Butterworth-Heinemann.

Koçyiğit, E. S. (2018). A Tale of Ulus Square: A Critical Assessment of Continuity, Transformation and Change in a Historic Public Open Space in Ankara, [Doctoral Thesis, Middle East Technical University, Graduate School of Natural and Applied Sciences]. Ankara.

Kosay, H. Z., (1935). Ankara Budun Bilgisi. Ankara: Ankara Community Center Publications.

Kuban, D. (2000). Tarihi Çevre Korumanın Mimarlık Boyutu. Kuram ve Uygulama, İstanbul: YEM Publication.

Küçükaltan, D., Oğuzhan, A., Apak, S. \& Boyacioğlu, E. Z. (2005). Bölgesel Kalkınmada Kültürel Turizmin Etkisi: Kırkpınar Yağlı Güreşleri Örneği, Trakya Üniversitesi Sosyal Bilimler Dergisi, 6 (1), 1-22.

Mazı, F. (2009). Tarihi Çevrenin Korunmasında Sosyo-Ekonomik Faktörlerin Etkisi. Mevzuat Dergisi, (138), 1-11.

Mckercher, B. \& Cros, H. (2002). Cultural Tourism, The Partnership Between Tourism And Cultural Heritage Management, New York: The Hawort Pres.

Richards, G. (1996). Production and Consumption of European Cultural Tourism, Annals of Tourism Research, 23(2), 261-283.

Richards, G. (2001). Cultural Attractions and European Tourism, New York: CABI Publishing.

Richards, G. (2018). Cultural Tourism: A review of recent research and trends, Journal of Hospitality and Tourism Management, 36:12-21.

Sevgi, S. (2020). Ankara Çukur, Çengel ve Safran Han Örneklerinde Yeniden Kullanım Müdahalelerinin Koruma Açısından Irdelenmesi ve Bir Değerlendirme Yöntemi Önerisi, [Doctoral Thesis, Gazi University, Institute of Fine Arts]. Ankara.

Tankut, G. (1984). Jansen Planı: Uygulama Sorunları ve Cumhuriyet Bürokrasisinin Kent Planına Yaklaşımı, E. Yavuz and Ü. N. Uğurel. (Editors). Ankara in History September 1981 Seminar Papers, Ankara: METU Faculty of Architecture Publications, 301-316.

Tekel, A., Kızıltaş, A., C. and Afshar, S. (2018). The Impacts Of Perception Criteria On Aesthetic Response To Urban Streets: A Case Study in Downtown Ankara, Turkey, Gazi University Journal of Science, 31(4): 9961005.

Tighe, A., J. (1986). The Arts/Tourism Partnership, Journal of Travel Research, 24(3): 2-5.

Tosun, C. \& Bilim, Y. (2004), Şehirlerin Turistik Açıdan Pazarlanması, Anatolia: Journal of Tourism Research, 15(2):125-138.

Tunçer, M. \& Cengizkan, A. (1996). Tarihi Kent Merkezlerinde Kentsel Yenileme ve Yenileşme, Ulus Tarihsel Kent Merkezi Planlaması Kapsamında Hacı Bayram Camii Çevre Düzenlemesi, 4. Urban Conservation, Renovation and Applications Colloquium, (İstanbul 4-5 April 1996). 
Tunçer, M. (2001). Ankara Şehir Merkez Gelişimi (14.-20. yy), Ankara: Ministry of Culture Publications.

Tunçer, M. (2014). Ankara'da Vakıf Mülkiyetindeki Bedesten ve Hanların Gelişimi ve Şehir Ekonomisinin Dönüşüm Süreci (15- 20. yy), Vakıf ve Íktisat Sempozyumu, Ankara: Vakıflar Genel Müdürlügü Yayınları, 103150.

Urak, Z., G. (1999). Ankara Ulus Koyunpazarı Yokuşu ve Hisar (Atpazarı) Meydanı'nda Zaman, Mekân ve Koruma Sorunları, Ç. Kafesçioğlu and L. T. Şenocak (Editors). Articles for Aptullah Kuran, Istanbul: Yapı Kredi Publications, 557-575.

Utkutuğ, Z., Urak, G., Sağlam, H. Aksulu, I., Akalın, A. \& Gültek, M. (1993). Tarihi Çevre Koruma-Yenileme Çalışmalarında Kentsel Bölge Ölçeği: Ankara Kale Önü Koyunpazarı Yokuşu Koruma-Geliştirme Projesi Örneği, Ankara University the Journal of The Faculty of Languages and HistoryGeography, 36(1-2): 421-436.

\section{Resume}

Filiz Karakuş received her B.Arch in Architecture from Middle East Technical University, Faculty of Architecture (2002). She earned her M.Sc. and PhD. degree in architecture from Gazi University, Faculty of Architecture (2012-2017). Currently works as an Assistant Professor at Ankara Ylldirım Beyazıt University. Major research interests include conservation and restoration.

Z. Gediz Urak received her B.Arch in Architecture from ADMMA (1974). She earned her M.Sc. from Middle East Technical University, Faculty of Architecture (1981) and PhD. degree in architecture from Gazi University, Faculty of Architecture (1994). She earned her Prof. Degree in architecture from Gazi University (2007). Currently works as Professor at Cankaya University. Major research interests include conservation and restoration. 